\title{
Mõningaid mõtteid kunstist, Kristjan Rauast ja vanavara kogumisest
}

\begin{abstract}
Kärt Summatavet
Teesid: Artiklis vaadeldakse 20. sajandil kujunenud probleeme professionaalses kunstiõpetuses, et selgitada lokaalse identiteedi ja kunstiloomingu seoseid tänases kunstielus. Artikkel uurib 20. sajandi alguses tegutsenud kunstnike tegevust esemelise pärandi ja kogumistöö mõtestamisel. Vaadeldakse empiirilise kogemuse ja kunstikategooriate rakendamise praktikat rahvakunsti ja professionaalse kunsti sidumisel Kristjan Raua folkloorialases loome- ja pedagoogitöös. Võrreldakse 20. sajandi alguse ja teise poole professionaalses kunstiõppes valitsenud meetodite ja rahvakunsti interpreteerimise eesmärke. Selgitatakse välitöömeetodite võimalusi pärimuskogukonna artefaktide autorite repertuaari uurimisel ja kunstiloomingu inspiratsiooniallika otsingutel.
\end{abstract}

Märksõnad: Kunst, rahvakunst, välitöö, professionaalne kunstiõpetus

Praeguses eesti kunstielus ei ole ühtset seisukohta, kuidas käsitleda pärimust nüüdisaegses võtmes, milliseid tekste võtta kunstiloomingu aluseks ning mida mõelda kiiresti muutuvas ja arenevas Eestis kohalikust rahvakunstist. Kunstnike peamine probleem on 20. sajandi lõpukümnendil kunstiellugi segadust külvanud identiteedikriis ja soov vabaneda nõukogude ideoloogia kujundatud stereotüüpidest. Kuigi rahvakunsti peetakse teatud liiki kunstiloominguks (Eesti Entsüklopeedia 1994: 674-675), pole kiired elumuutused ja kunstnikele avanenud uued väljakutsed võimaldanud tõstatada laiemat arutelu rahvakunsti tähtsuse ja väärtuse üle, ehkki professionaalne muusikaelu, pärimusmuusika ja laulupidude traditsioon on samal ajal läbi teinud juba mitmeid selgelt jälgitavaid arenguid. Pärimusest inspireeritud uus kunst ja disain, mis kannavad omaenda kultuuriruumi olulisi väärtusi, arendades ja laiendades nüüdiskunsti võtetega järjepidevuse sümboleid ning avardades kohaliku kunstiloomingu tähendusvälju, võivad muu hulgas toetuda ka eelmise sajandi alguses tegutsenud kujutavate kunstnike ja kunstipedagoogide kunstiteoreetilistele kirjutistele ja mõtteavaldustele, mille taasavastamine aitab ületada tänaseid probleeme. 
Etnoteemad ja folkloor on viimastel aastatel maailma tippmoes, disainis ja nüüdiskunstis tõusuteel, kuid eesti kunstielus ja omamaises disainitoodangus on kohaliku pärimuse teemadel loodud veel üsna vähe silmapaistvaid uusi suundi või lahendusi. Probleemi sügavamad juured peituvad noorema põlvkonna kunstnike väheses kultuuri- ja ajalootundmises ning olulist mõju avaldab noorte valikule ka 1990. aastatest alates valitsev kunstipoliitikute leige huvi pärimusele toetuvat lokaalset identiteeti käsitleva kunstiloomingu vastu, samuti tööstusettevõtete liigne orienteeritus välismaiste allhangete täitmisele. Kunstihariduses valitseb ka mõningane segadus mõistete ja tõlgenduste osas ning tihti tundub, et kaugeid maid ja rahvaid on kergem uurida ja loominguvankri ette rakendada, kui oma ja unustatut. Noored kunstnikud ei suuda end samastada 20. sajandi alguse esemelise pärandi loojatega ning rahvakunsti sisu jääb neile kaugeks. Kui muusikud pakuvad üha enam huvitavaid tänapäevaseid lahendusi oma valdkonnas, siis kunstis ja disainis seisab omakultuuris peituva loomepotensiaali taasavastamine ja sellele uute tähenduste võimaldamine alles ees.

Eesti Kunstiakadeemia õppejõu töös omandanud kogemused annavad küllaltki hea ülevaate probleemideringist, mida kohtab noor kunstnikepõlvkond kohalikku folkoori interpreteerivate õppeülesannete raames. Rahvakunst on ühest küljest oluline ja inspireeriv õppetöö teema, mis annab üliõpilastele võimaluse tutvuda folkloori ja muuseumikogudega, ent kohustusliku õppeaine lõppedes jäävad pärandi teemad uute loominguliste katsetuste varju ning enamasti ei jätkata pärimuse teemaga sügavuti tegelemist. Noortel jääb puudu teadmistest, kuidas ühendada esemekogusid kaasajaga ning mil moel mõtestada vanu kultuuritekste aktuaalsete ja populaarsete kunstiteemade valguses. Üliõpilastel on lihtsam võtta artefakte otseste eeskujudena oma loomingusse üle ja sobitada efektseid või armsaid detaile õppeülesande vormiliste eesmärkidega. Palju raskem ja töömahukam on koguda loometööks uusi sisulisi teadmisi ja luua rahvakunsti teemal nüüdisajaga haakuvat uut kvaliteeti.

Noori kunstnikke peletavad pärimusest eemale ka Eesti rahvakunsti vanemad käsitlused, mis tegelevad peamiselt talurahva tarbeesemete pinnakujunduse ja kaunistuste (kiri) (Eesti Entsüklopeedia 1987: 439-441) probleemideringiga. Esemete kaudu väljenduva 'ilumeele' rõhutamine, mis on siiski üsna ühekülgne lähenemine, jätab liiga vähe võimalusi visuaalse kommunikatsiooni võtete, artefakti funktsioonide ja vaimse kultuuri seisukohast oluliste tähenduste uurimisele. Kunstivaldkonna seisukohast vajalikud uurimisteemad on seotud aga inimese kui loojaga ning võimaldavad jälgida pärimuse kandjate loomingulise eneseväljendusvõime sotsiaalseid ja kultuurilisi tagamaid. Tänaseid kunstnikke huvitavad esemeid loonud autorid ja nende käest kogutud lood, mis aitavad lähendada kunstnikku rahvakunsti teemadele. Just inimese 
osa esemetes (Honko 1998: 63) pakub huvi ja teeb mõistetavaks artefakti valmistaja loomeprotsessi, mille käigus elava pärimuse sees luuakse isikupäraseid ja uuenduslikke variante ning avardatakse pärimuse piire. Oma kogemuse põhjal võin väita, et omamoodi takistuseks rahvakunsti teema kvalitatiivsele arengule kunstihariduses on saanud rahvakunsti pärandi autorluse vähene tundmine ja asjaolu, et esemelist pärandit on Eestis käsitletud valdavalt anonüümsena. Kuid artefaktil on alati autor, valmistaja, tellija ja kasutajakandja. Ühte konkreetsesse kogukonda kuuluvate inimeste mõtted, ideed ja esemete valmistamise protsess, mille ühendamise tulemusel valmib konkreetne artefakt, kannab ühelt poolt hinnalist informatsiooni vaimse kultuuripärandi väärtustekogumist, mida esemete kaudu väljendatakse ning teisalt kõneleb autori isiklikest valikutest, oskustest, võimekusest ja loomingulisest küpsusest. Autorlusega seotud teemade võtmes muutub esemeline pärand kunstniku silmis huvitavaks ja oluliseks kultuuritekstiks, mida tasub tundma õppida, mõista ja kaasaegses kunstikeeles edasi arendada.

Eesti Kunstiakadeemia praktikas on rahvakunsti interpreteerimisel olnud oluline roll ning Eesti 20. sajandi professionaalse kunstihariduse ühe eriharuna on ülikool järjepidevalt sidunud õppetöös rahvakunsti ja kunstiloomingut. Kuid õppeülesannete püstitus, juhendamine ja õppejõudude nõudmised ning ootused on eelmise sajandi jooksul läbi teinud hulga muutusi, mistõttu praegu oleme jõudnud murrangulisse punkti, kust edasi liikumiseks on vaja teha korrektuure ning uuesti avastada juba ununenud tekste. Tänase kunstiakadeemia valdavalt muuseumite kogudele rajatud õppepraktikate süsteem ei paku kunstiõpilaste kujutlusvõimele ja eneseväljenduspürgimustele küllaldaselt inspiratsiooni, sest loomulikust keskkonnast eraldatud artefaktid ei anna noortele piisavat ülevaadet inimese ja tema loodud esemelise pärandi omavahelistest seostest. Pelgalt vormi, lõigete, värvikombinatsioonide ja ornamentide kopeerimine või stiliseerimine ei paku innustavaid loomeimpulsse uute lahenduste leidmiseks kasutajakeskses disainis. Vähesed kultuuri- ja ajalooteadmised takistavad nägemast eelmise sajandi algusest muuseumikogudesse laekunud esemete valmistajaid mõjutanud kohalikku kultuuritausta ning inimeste kogemusi, ideid ja emotsioone. Ka esemete kaudu väljendatud sõnumeid ei osata märgata enne, kui ei leidu pädevat teejuhti, kes neid arusaadavaks tõlgiks. Probleemi juured on ka selles, et ei osata kokku viia esemelist ja suulist pärandit.

Tänaseni säilinud rikkalikud eseme- ja käsikirjakogud riigi- ja eramuuseumites ning erakätes hoitud perekonnakogudes on piisavad, et leida omanäolist inspiratsiooni ja luua uusi, kogu Euroopa kultuuriruumi rikastavaid ja vaimustavaid kunstiteoseid või disainitooteid. Kui varasem uurimistraditsioon on keskendunud esemete väljanägemise uurimisele ja tüpologiseerimisele, siis 
tänaseid kunstiüliõpilasi vaimustab eelkõige visuaalsel kujul esitatud kultuuritekstide valmistajate ja kandjate "oma hääl", informantidelt kogutud lood, mis aitavad kunstnikul näha ja hinnata rahvapäraseid loomeimpulsse. Neid tekste mõistes ja professionaalsel tasemel interpreteerides muutub kunstniku looming sügavamaks ning tekivad uued seosed mineviku ja kaasaja mõtestamiseks.

\section{Kunstnikud - pärimuse kandjad}

20. sajandi alguses käivitunud esemelise pärandi kogumise aktsioone juhtinud või kogumistöös osalenud kunstnike puhul tuleb märkida, et möödunud sajandi alguse kunstnikud olid enamasti ka ise pärimuse kandjad. Tänaste noorte kunstnike perekonnalood on aga seotud sajandipikkuse linnastumise ja nõukogude-aegse ideoloogilise surve järelmõjudega ning pärimusest ollakse juba enamasti kaugenenud, lugusid ei mäletata. Kuid 20. sajandi alguse kunstnikel ja kunstiõpilastel oli side eelmiste põlvkondade pärimusega säilinud, nad olid ise pärimuse keskel üles kasvanud ning saanud vanematelt kaasa võime näha ümbritsevat elavat pärimuskeskkonda omaenda kogemustele toetudes. Võib arvata, et kunstnikud said juba kasvatusega kaasa võime "näha asjade ja lugude taha" ning kogumistöö käigus märkasid nad pärimuses ja inimeste käitumises või kommetes inspireerivaid seiku, millele professionaalses loomingus toetuda (Summatavet 2005: 40). Uudishimulikule ja empaatilisele kunstnikule on nö nähtamatud tekstid aga peamine inspiratsiooniallikas, mis tõukab neist kõnelema ning edasi andma oma töö- ja väljendusvahenditega. Möödunud sajandi alguses tegutsenud kunstnike kogumistöö aktuaalsuse ja hädavajalikkuse tingisid kiiresti arenev linnastumine ja manufaktuuride toodangu levik - varem kasutusel olnud esemed muutusid ebavajalikuks, traditsioonilised loomeoskused ja töövõtted kaotasid algse tähenduse ning kadusid kiirelt aktiivsest kasutusest (nt kogumisaruanne Kehrast 18.09.1910. ERM TAp 4: 2). Ka kunstnike lapsepõlvekodudes leidus algupärases miljöös küllaldaselt esemeid, mida valmistati, kasutati ja säilitati ning millel oli oma lugu, kuid uues situatsioonis hakkasid nad kaotama oma senist funktsiooni.

Kogumistöö eestvedajatena tegutsenud 20. sajandi alguse eesti kunsti suurkujud Kristjan Raud ja Ants Laikmaa olid nii mõttekaaslased kui ka lähedased sõbrad. Esimesed otsustavad sammud eesti kunstiteoreetilise mõtte arengusse tegid nad üheskoos ning on teada, et näiteks A. Laikmaa kunstiliste tõekspidamiste esimene säilinud ülestähendus pärineb Kr. Raua sulest (Viiroja 1970: 89). Kuigi A. Laikmaa tegevus oli seotud peamiselt Tallinna kunstieluga ning Kristjan Raud tegutses kuni 1914. aastani Tartus (Pihlak 1970: 80), on kahe 
kunstniku koostöö ja kunstilised tõekspidamised lähedased. Lehti Viiroja järgi võib mõlema kunstniku ühiseid seisukohti leida juba Düsseldorfis õppimise aegadest pärinevatest kirjadest ja kirjutistest ning ka hilisematest kirjalikest mõtteavaldustest (Viiroja 1970: 91-96; Kangro-Pool 1961: 24-25). Seetõttu pole ka nende esemelise vanavara kogumistöö algust võimalik vaadelda lahus, sest mõlemad kunstnikud olid sellega seotud ning 1905. aastal käisid nad üheskoos Õpetatud Eesti Seltsi ülesandel etnograafilisele osakonnale esemeid kogumas (Pihlak 1970: 80). Selgema ülevaate saamiseks on otstarbekas vaadelda koos mõningaid Kr. Raua ja A. Laikmaa mõtteavaldusi 20. sajandi alguse kunstiteoreetilistest püüdlustest, eesti esemelise pärandi kogumisest, tutvustamisest ja kunstihariduse arendamisest.

Kr. Raud ja A. Laikmaa kasvasid pärimuse keskel, said folkloorse mõtteviisi oma kasvatusega kaasa ning olid ise pärimuse kandjad. Nad elasid kaasa oma rahva raskele saatusele ${ }^{1}$ ning püüdsid mõista eesti kultuuri sügavusi. A. Laikmaa kogus juba nooruses oma pere ja kodukoha laulu- ja juturepertuaari. Ta oli rahvaluule korjamisest osa võtnud juba 1896. aastal ning saatis Jakob Hurdale Läänemaa rahvalaule, rahvajutte ja naljandeid (Tiik 1964: 36; Põldmäe 1942) ning kogus emalt noorpõlves kuuldud laule, õelt ja õemehelt üles kirjutatud laule, vana möldri Laulu-Juku repertuaari - kokku 240 lehekülge tihedat teksti. Ta tundis kodukandi ja laiema ümbruskonna rahvaluulet päris hästi ning armastas oma kirjutistes kasutada rahvapäraseid kõnekäände ja rahvalauluvärsse, ka sakstevastaseid pilkelugusid. Endel Nirk kirjutab:

Suulise pärimusvara kogumisel ja muidu külades ringi rändav kunstijünger märkas terasema pilguga kui teised kaasaegsed muudki kogumisja säilitamisväärset - esemelist vanavara, rahvakunstinäiteid. Milliseid suurepäraseid värvikirevaid vöösid, kindaid-sukki, tanusid ja muid rõivastusesemeid, voodivaipu, saanitekke jms võis taluperedes näha, missuguseid nikerdatud toole, vaalikurikaid, koonlalaudu, sisselõigatud või põletatud kirjadega õllekanne! Ja kõik see oli suurelt osalt kadumisel, kõrvaleheitmisel või juba kõrvale heidetudki, taandumas uuema-aegse ilmetuma-ilutuma toodangu või linnalise päritoluga poekauba ees (Nirk 1977: 48).

Kr. Raud saatis kogutud rahvaluulet Jakob Hurdale ja Johann Voldemar Veskile (EKLA Kr. Raud f 157, m 13:3; f 157, m 13: 10) ning suhtles Johann Mattias Eiseniga (EKLA f 25, m 12:28). Esemelise pärandi kogumisel kohtusid Kr. Raud ja A. Laikmaa, kes tutvusid 1897. aastal ja said peagi lähedasteks sõpradeks (Nirk 1977: 58), külades paljude inimestega ning kunstnike kirjutistes, üleskutsetes ja käsikirjades leidub piisavalt märkmeid, mis tunnistavad, et kogumistöö käigus kuuldud teated avaldasid kunstnike mõtetele ja arvamustele 
otsest mõju. Arhiividokumentide põhjal selgub, kuivõrd lähedane ja inspireeriv oli mõlemale kunstnikule isiklik kogemus ja side rahvakunstiga ning kuidas nad tegevkunstnike ja pedagoogidena püüdsid mõtestada neid isiklikult puudutanud orjastatud rahva ajalugu, mõttemaailma ja loomingut.

Professionaalsete kunstnike treenitud märkamisvõime võimaldas siduda rahva seast kogutud suulisi teateid ja esemeid ning vaadelda neid omavahel seotuna. Mujal Euroopas ja Põhjamaades rahvakunstile pühendatud muuseumid ning nende eeskuju andsid omalt poolt tõuke koguda Eesti külades kaduma hakkavat esemelist pärandit. Akseli Kallén-Gallela, Nikolai Roerich ja Edward Munch olid pälvinud oma loominguga juba suurt tähelepanu ning $\mathrm{Kr}$. Raual oli kerge põhjendada oma kaasaegsetele ja õpilastele, miks tasub omavahel siduda rahvakunsti ja professionaalset kunsti (EKLA f 74, sinine märkmik: 23-25). Osavate interpreteerijate ja portretistidena oli Kr. Raual ja A. Laikmaal rahvakunsti päästmisel märkimisväärseid eelised teiste uurijate-kogujate ees, sest kunstipraktikute ja pärimuse kandjatena ühendasid nad rahvaluulet ja esemelist pärandit, pealtnäha erinevaid kultuuritekste, nii oma kirjutistes kui ka loomingus. Endel Nirgi järgi oli mõlemale kunstnikule kunsti teenimine isiklik kutsumus ja kirg ning ühtlasi ka oma rahva, ühiskonna, üldinimliku hüve teenimine (Nirk 1977: 105). Kui Jakob Hurt käivitas ülemaalise rahvaluulekogumise aktsiooni seoses rahvaluule kiire kadumisega, asus 1904. aastal Tartusse kolinud Kr. Raud koos sõbra A. Laikmaaga ligi pool sajandit hiljem päästma kiiresti kaduma hakanud esemelist vanavara, sest hävimisprotsess oli juba sajandivahetusel selgelt näha. Ühiste eesmärkide ja pühendunud tegevuse tõttu valiti mõlemad kunstnikud Hurda matusepäeval toimunud koosolekul 1907. aastal ERMi ettevalmistavasse toimkonda (Nirk 1977: 156). Teiste maade eeskuju lisas selleks veelgi hoogu ja ühiskonna silmis kaalukust. Pikema kogumisretke tegi A. Laikmaa 1904. aastal ning lasi valmistada oma korterisse enda kavandite järgi rahvuslikus stiilis sisustust (Nirk 1977: 118).

\section{Kunstnikud ja vanavara}

Mõiste vanavara tähistas algselt suulist pärimust. ${ }^{2}$ Raud hakkas mõistet vanavara kasutama oma üleskutsetes rahva kunsti kogumiseks ning nimetas vanavaraks eestlaste endise aja kunsti, mis oli rahva loomise võime, ilumaitse ja vaimurikkus. Ta nimetas eestlaste esivanemaid väledaks, mõtlejaks, lauljaks rahvaks, kes vikerkaare taevast maha tõi ja enese ümber ehteks mässis (Mõtteid Eesti kunstnikkude ja kunstiõpilaste tööde näituse puhul, Postimees 16.04.1909). Raua elutöö teedrajav kirjutis "Kunst eesti käsitöös" (1904) tut- 
vustas avalikkusele kunstniku tähelepanekuid ja veendumusi ning lõi aluspõhja kõigile tema hilisematele kirjutistele, üleskutsetele ja märkmetele. Esitatud mõtisklused järgisid Kr. Raua kogemusi kunstnikuna ning tõid lugejale avalikult nähtavale, kuidas siduda omavahel rahvaloomingut ja inspiratsiooni. Kr. Raud kirjutas:

Ilu loomine oli Eestis muistsetel aegadel kõrgemal astmel olnud kui praegu; seda tunnistavad rahvaluule, seda tunnistavad endised Eesti ehted ja kaunistatud majaasjad. Puhtast Eesti südamest voolas hää ja kenaduse tunne, tema laul ilustas tema kätetööd ja eluruumisid ning ülendas ja pühendas tema elu. [---] Kuidas need üksikud ained kaunisti kokku on seatud ja elustatud, kuidas värvid kokku passitud, seda vaadaku ja imestagu igaüks ise ja katsugu ka sel kombel teha. Üle kõigi nende väikeste loodusekenaduste mõju mõjusid iga-aastased suured looduse-avaldused ning nende võimsad põhjamaalised värvikõlad vägevasti inimese pääle ja sünnitasivad meie rahva põhjustunded. Nõnda siis võib lõpuks ka vanade Eesti rahva sünnituste ja kunsti-kanga kohta öelda: Loodus andis lõimed ja inimene kudus koed sisse (vt Raud 1904: 672-675).

Kr. Raud ühendas siin professionaalse kunstniku kogemused rahvakunstiga ning avas kirjutises uued võimalused esemelise pärandi analüüsimiseks. Ta rõhutas ka hiljem, et iga tõsine kunst ja püsiv kultuur tärkab kodumaa põuest, rahva hinge sügavusest. Ta on taim, mis juureta ei kasva. Alt mullapinnast sirgub ta otse üles, mitte külgepoogituna (Raud 1937: 4).

Kr. Raua mõtetele ja tegevusele avaldas suurt mõju A. Laikmaa, erakordselt hea suhtleja ja visionäär, kes oma isikuomaduste tõttu oli vanade asjade korjamistöös väga edukas. A. Laikmaa erakordsed isikuomadused mõjusid nii, et inimesed usaldasid tema kätte oma perekonna väärtusi, sest kunstnik oskas neile arusaadavalt ja kiindumusega selgitada muuseumi vajalikkust. Kogudesse esemete andmine kujunes mõnel pool lausa prestiiži küsimuseks (vt Laikmaa 2001: 228-229). Ka oma kunstikursustel pööras A. Laikmaa suurt tähelepanu õpilaste harimisele ning käis mitmete õpilastega kogumisretkedel mööda Eestit. Ta oli veendunud, et kaasaja kunst leiab arengujõulise aluspõhja vanas rahvakunstis, mida on vaja korjata, austada ja säilitada (Hans Laipmann 1903). A. Laikmaa, kes hoolitses Õpetatud Eesti Seltsi vanade eesti esemete kogu täiendamise eest, käis hiljem külades esemeid ka oma erakogu tarbeks juurde kogumas ning võib vaid arvata, kui suurt mõju avaldasid 1905. aasta suvel koos Kr. Rauaga seltsile esemeid kogudes (Õpetatud Eesti Seltsi koosolek, Postimees 1906, 4. mai) tema vaated ka Kr. Raua arvamustele ja vastupidi. Ka L. Viiroja märgib, et kunstnike koostöö mõjutas juba 19. sajandi lõpust alates oluliselt nende ühiseid eesmärke ja tegevusi eesti rahvusliku kunsti mõtestamisel ja loomisel (vt Viiroja 1970: 97). 


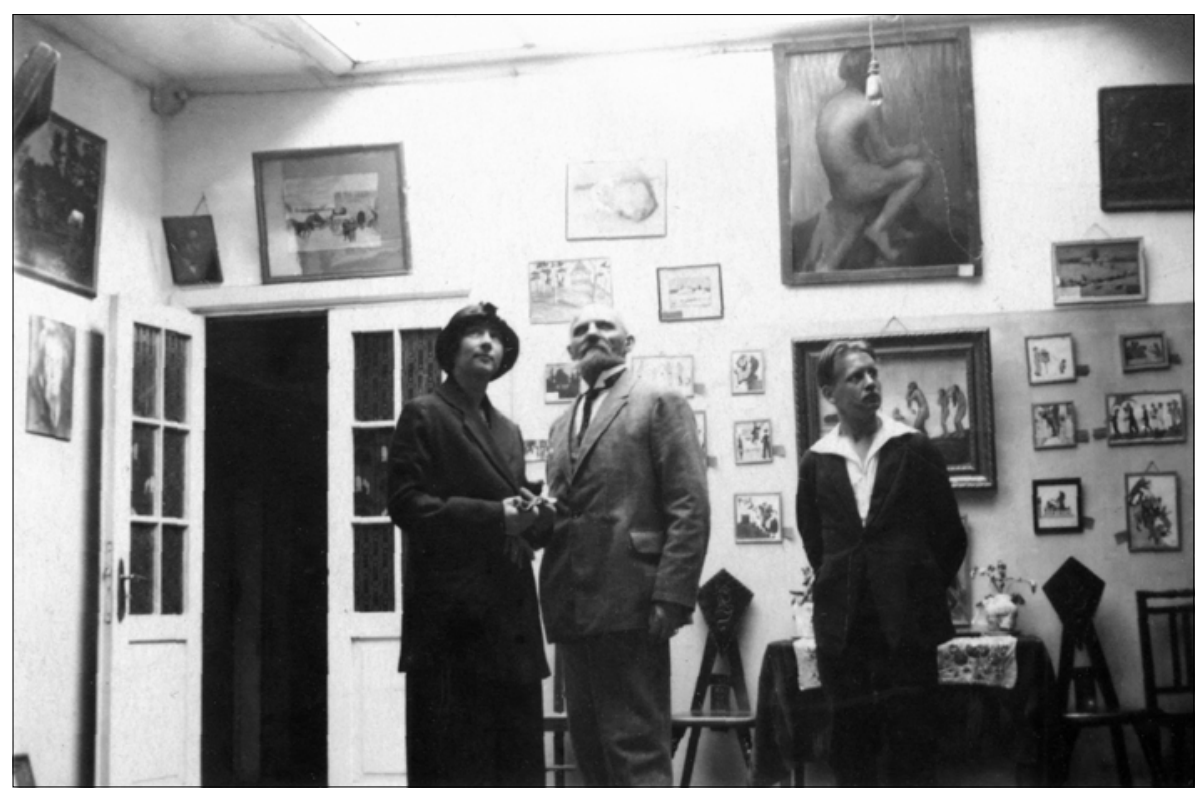

Ants Laikmaa (keskel) ateljees. KM EKLA A-58:29

A. Laikmaa tõstis teadlikult küladest kogutud esemed samale väärtusastmele professionaalse kunstiga ning see oli Eestis uudne nähtus, mis äratas huvi kaasaegsetes ja ajakirjanduseski. Näiteks 1905. aastal Tallinnas A. Laikmaa korteris toimunud kunstikursuste ülevaatenäituse kohta ilmus imestavaid artikleid, sest korteri ja kunstikursuse tööruumide sisseseades lihtsad Eesti toolid, vaibad, toakraam väikesest asjast kuni suureni-kõik täitsa vanaEesti laadilised olid. Ta toad näevad kui vana-Eesti asjade museum välja. Möödaläinud suvel käis kunstnik kõiksugu Eesti mälestusi korjamas. Ta tunneb tekist ära, kus ta valmistatud (Wõhandu 1905). Kunstikursuste ülevaatenäitus üllatas nii vaatajaid kui ka tellijaid, sest Eestis ei olnud keegi taibanud vaadelda eestlaste "vana aja kunsti" kui kaasaegse kujutava kunsti võrdväärset partnerit.

Kr. Raud oli veendunud, et ükski ajalainetus ega individualistlik suurtalent ei suuda muinaslugude sügavusi ületada, küll aga võivad kunstnikud sealt palju õppida, kui nende lugude sümboleid osatakse mõista (Kangro-Pool 1961: 63). Ta rõhutas, et esivanemate kirjadega kaunistatud esemed on sündinud sügava mõttega ega ole juhuslikult kokku seatud. Vanavara on välja kasvanud inimese hingest ning esemete kaudu võib näha, kui peenelt rahvas kunsti asjus mõistab mõtelda ja tunda. Kr. Raud pidas kaunistatud esemeid rahvakunsti aabitsaks (EKLA f 186, m 202: 1). A. Laikmaa ja Kr. Raud pidasid esivanemaid kunstiliselt andekateks ning rõhutasid esemelise pärandi kasvatuslikku, 
maitset arendavat ja kunstiliselt suunavat mõju. Oskar Raunami järgi oli rahvakunst aluseks professionaalses kunstis eesti stiili otsingutele (Raunam 1964: 11). Kr. Raud oli vaimustunud lapselikust loomisrõõmust, mida eelmised põlvkonnad käsitöö kirjade ja värvide kaudu väljendasid: Kena kiri ehk ornament mis ta muud ongi kui luule, kui nähtavasse tõusnud laul. (Kristjan Raua kiri Oskar Kallasele (EKLA f 186, m 202: 1, lk 62)). Raud pidas esivanemate loomingu inspiratsiooniallikaks loodust ning arutles: Kinnaste 'külma-kirjad' polnud muud, kui lumekibemete järelkujutused. Lumekibemed langesivad tumeda põhjaga käevarjude pääle, kuni need üleni tihnitähniliseks saivad. Kentsakas kirju kiri meeldis ja meelitas järeltegemisele (Raud 1904: 672; EKLA f 186, m 202: 1, lk 63).

Kr. Raud oli kogumistoimkonna tööd juhtides kursis vanavara kogujate poolt Eesti Rahva Muuseumile toodud esemetega ning kasutas kogudesse laekunud esemetest saadud inspiratsiooni hiljem nii eepose Kalevipoeg illustreerimisel kui ka muus loomingus ja pedagoogitöös. Gustav Matto kirjeldab, kuidas $\mathrm{Kr}$. Raud muuseumis olles harilikult tundideviisi soris ja uuris esemeid, eriti kirjatud esemeid (ERM EA varia 16: 12). Kr. Raual oli õigus esemeid ka koju viia ning ta kasutas peamiselt kirjatud käiseid ja tanusid, kuna töötas parajasti Juhan Liivi luuletuskogu uue väljaande illustreerimisega. Laenatud esemed tõi ta tagasi alati pestult ja triigitult. Kui muuseumi saabusid uued vanavarakogud, oli Kr. Raud alati kohal esemete lahtipakkimisel, et näha, mida pakub vanavara ala uus kihelkond (Matto 1965, EA varia 16: 13). Ka Oskar Raunami järgi kasutas Kr. Raud esimese kunstnikuna rahvusornamenti raamatukujunduses Juhan Liivi Luuletused illustreerimisel juba 1910. aastal (Raunam 1964: 9-10). G. Matto järgi viibis Kr. Raud muuseumis väga palju: Vähe jäi päevi vahele, millal ta siin ei viibinud. Ta toonitas korduvalt, et tema elu peamiseks ülesandeks on luua võimalus täieliku ja kõikehaarava pildi saamiseks meie rahva eluolust minevikus. Seda vajavad meie tulevased kirjanikud, kunstnikud ja teadlased (ERM EA varia 16: 8-9).

A. Laikmaale meeldisid tekstiilesemete pastelsed ja looduslikud värvitoonid: Eestlase, st endise eestlase-talupoja värvid olid kahvatud, so polnud eredad, kirevad, sest ta ümber ei leidunud veel väljast sisse toodud eredaid, kirevaid, kunstlikult valmistatud vabrikuvärve, ta otsis ja valmistas oma värve alles metsast, loodusest, sammaldest jm - niisiis ka siin natura artis magistra (loodus on kunsti õpetaja). Need värvid olid lihtsad-ilusad, vaiksed ja tagasihoidlikud-harmoonilised ja siiski an sich (iseenesest) väga värvikad (Laikmaa 2001: 167). Lehti Viiroja järgi kasutas A. Laikmaa esimesena oma ateljee interjööris enda kavandatud talupojalaadset juugendlikku mööblit ning sobitas neid kokku rahva käest korjatud etnograafiliste vaipade ja tekkidega. A. Laikmaale olid eeskujuks soomlased, kes oma töödele Soome iselaadi pü̈̈avad anda ja Soome muinasloost oma mõtteid võtavad (Laikmaa 2001: 441). 
Kr. Raua ja A. Laikmaa tekstid on ühest küljest haaravad ja sütitavad üleskutsed ning aitavad näha paljude kaasaegsete arvates väärtusetut koli ja rämpsu samaväärsena professionaalse kunstiga. Kirjutised aitavad selgitada, miks pöörasid välismaal õppinud loomingulised professionaalid nii palju tähelepanu uuendusi ja paremat elu ihkavate eestlaste vanadele esemetele. Tänasele lugejale tunduvad need tekstid kohati üpris naiivsed ja kohmakad, kuid neid ei saagi võrrelda harjumuspäraste teadustekstidega. Kr. Raua ja A. Laikmaa kirjutisi tuleb hinnata kui kunstnikutekste, mis sisaldavad küll ohtralt isikupäraseid romantilisi heietusi, kuid avavad kunsti seisukohalt olulisi kultuuritekste ja tähendusvälju, mida 20. sajandi alguses oli veel selgelt võimalik jälgida elavas keskkonnas.

Need kirjutised inspireerivad ka noori kunstnikke märkama Kr. Raua ja A. Laikmaa tähelepanu köitnud kultuurinähtusi, püüdu selgitada esemete kaudu väljendatud kogemusi ja mõttemaailma, mida nad jälgisid ja analüüsisid kunstnike-praktikutena. Kirjutiste tähelepanekud erinevad professionaalse loomingulise ettevalmistuse tõttu kõigist teistest möödunud sajandi alguse uurijate tekstidest, sest kõnelevad rahvakunstist kunsti kategoorites ning pööravad tähelepanu artefaktide loojatele kui kunstnikele ja nende loomingule. $\mathrm{Kr}$. Raua ja A. Laikmaa tekste on siiski peetud eelkõige kunstivaldkonda kuuluvateks ning neile pole esemelise pärandi uurimise seisukohast hiljem erilist tähelepanu pööratud. Inimese ja tema loomingu vahelise seose otsimine rahvakunstis ning nii suurte kunstnikuüldistuste tegemine ei ole uurijale mõistetavad, kunstnikust praktiku kogetud ja sõnades väljendatud tähelepanekute sisu jääb enamasti teadusele kaugeks ja võõraks, sest emotsionaalne ja subjektiivne tekst ei ole piisavalt usaldusväärne. Kuid kunsti seisukohalt on need tekstid erakordselt huvitavad kui kahe kunstniku-informandi teated, kes annavad edasi oma arvamusi ja tähelepanekuid esemelisest kultuurist ning inimeste loomingulisest eneseväljendusest.

Sajanditaguseid dokumente lugedes peame arvestama ka seda, et mõlemad kunstnikud kirjeldasid ja püüdsid edasi anda midagi sellist, mille kirjeldamiseks puudus Eestis harjumuspärane sõnavara ja eelnev uurimistraditsioon. Kuigi kunstnike tähelepanekud ja seosed tunduvad tihti liiga lihtsustatud ja luulelised, kohati naiivsed ja otsitudki, tuleb tunnistada, et kirjutiste kaudu avanevad oma ajas uued võimalused, mille kaudu läheneda rahvaloomingu pärandile. Tähelepanuväärne on ka asjaolu, et need tekstid olid suunatud märkimisväärselt laiale sihtrühmale ja püüdsid kõige muu kõrval valgustada ka professionaalse kunsti olemust, vajalikkust, väärtust, mis vajas eesti ühiskonnas tol ajal samuti põhjalikku selgitust. 


\section{Vanavara koguja argipäev}

Kunstnike vanavara kogumine algas juba enne muuseumi asutamist. Hilja Silla järgi ergutas juba Johann Köler eesti rahvusliku liikumise tegelasi J. Adamsoni, J. Kunderit ja H. Wühnerit 1870. aastal koguma eesti rahvarõivaid Peterburis asutatud kunsttööstusmuuseumile (Sild 1972: 63). Eesti Rahva Muuseumi asutamise eellugu ning silmapaistvaid tegelasi muuseumi asutamise algaastatel on kajastanud mitmed varasemad uurimused ja artiklid (nt Raud 1907; Manninen \& Leinbock 1925; Leinbock 1934; Kangro-Pool 1961: 66-84; Linnus 1970a: 226-245; Linnus 1970b: 247-258; kogumik Kristjan Raud. Ants Laikmaa. 1970; Õunapuu 1990, 2001 ja 2007), mida lähemalt tutvustada ei ole käesoleva artikli eesmärk. Muuseumite kogudes on muu hulgas nii Kr. Raua kui ka tema kaasaegsete meenutusi kogumistööst, kuid eraldi tulevad vaatluse alla vaid kaks ERMi käsikirjaliste kogude dokumenti, mis aitavad selgitada kunstniku töömeetode ja loometöö taustu. Dokumentide autor on Gustav Matto, kes Kr. Rauaga muuseumi algaastatel koos töötas ning vanas eas oma meenutused Oskar Kallase palvel üles kirjutas. Gustav Matto (töötas ERMi Seltsis 1910. aastast 1917. aasta oktoobrini, (G. Matto, EA varia 16: 1)) kirjutatud käsikirjalised mälestused aitavad näha Kr. Raua inimlikku poolt ning raskusi ja rõõme, millega ta kogumistöö juhina kokku puutus. Kunstnikust lugejale annavad G. Matto meenutused uusi teadmisi, millele kunstiajaloolased ja Kr. Raua loomingu analüüsijad pole varem nii otseselt tähelepanu juhtinud. G. Matto meenutused võimaldavad avada kunstniku mõtteavalduste tagamaid uuest vaatenurgast ning mõista tema ühiskondliku tegevuse ja loometöö omavahelisi seoseid.

G. Matto järgi alustas eesti etnograafiliste esemete kogumist Õpetatud Eesti Selts $^{3}$ ning kui 1896. aastal Riias toimunud arheoloogilisel näitusel olid välja pandud ka läti rahvarõivad, asuti ÕESis kogumistööle uue hooga. G. Matto meenutuste järgi kogunes seltsile päris kena kogu eesti rahvarõivaid siis, kui kogumistööle asusid seltsiliikmed Kr. Raud ja O. Kallas. J. Hurda surma järel asutatud ERMi Selts alustas kogumistööd juba laiemalt ning eesmärgiks seati sõnalisele vanavarale lisaks ka helilist ja esemelist koguda (Matto, EA varia 16: 1).

G. Matto puutus oma sõnul muuseumitegevusega kokku juba selle algusest peale ${ }^{4}$, kuid ERMi töö kandvad jõud olid Oskar Kallas (seltsi juhatuse esimees), Karl Eduard Sööt (juhatuse sekretär) ja Kr. Raud (vanavarakogumise toimkonna juhataja). G. Matto: O. Kallasega olin juba varem kokku puutunud ja tuttav, kuna võtsin osa tema poolt EÜSi ruumides korraldatud soome keele kursustest, ka K. E. Söödiga olin juba keskkooliõpilasena kokku puutu- 
nud, K. Rauda tundsin, nagu tuntakse silmapaistvaid inimesi, tuttav isiklikult aga seni ei olnud (Matto 1965, EA varia 16: 2). Peale Kr. Raua ja A. Laikmaa valiti muuseumi juhtivatesse kogudesse ka teisi silmapaistvaid kunstnikke: Amandus Adamson, August Weizenberg (mõlemad 1909), Alma Johanson-Koskel (1912-1918), R. Lepik (1915), A. Tassa ja M. Pukits (mõlemad 1920. aastail) (Sild 1972: 60). O. Kallas kui seltsi juhataja kandis muuseumi töö eest tervet vastutust ja lahendas koos K. E. Söödiga vahekorrad ametiisikutega (linna- ja vallavalitsustega, politseiga, kubermangu ülematega) (Matto 1965, EA varia 16: 2). Väljasaadetavatele vanavarakogujatele (selleaegse nimetusega vanavarakorjajad) andis ta praktilisi näpunäiteid ning õpetas, kuidas käituda pikematel teekondadel, kuidas riietuda, millised jalatsid kaasa võtta jne. Kokku tulnud esemete vastu ta erilist huvi ei tundnud (samas: 3 ).

Kr. Raud vajas kogumistööd rahva kunstiloomingu tundmaõppimiseks (samas: 1) ning toonitas korduvalt, et tema elu peamiseks ülesandeks on luua võimalikult täielik ja kõikehaarav pilt meie rahva eluolust minevikus (samas: 8). Kogumistöö juhina määras ta muuseumikogudesse korjatavate esemete valikuprintsiibid ja maitse-eelistused. Ilmari Manninen arvab hiljem, et korjajad jätsid kahe silma vahele nii mõnegi asja, millel puudus meeldiv välimus: On asi iseäraliku kujuga, siis on korjaja ta kaasa võtnud, kui mitte - siis harilikult maha jätnud. Sellepärast peabki ütlema, et senised kogud küll täidavad Eesti rahvakunsti muuseumi ülesannet, sellevastu rahvateadusliku muuseumi ülesannet mitte (vt Õunapuu 2001: 126). Kuid samas hindas I. Manninen kõrgelt variantide rohkust, mis võimaldas esemekogudes väga põhjalikku uurimistööd läbi viia. I. Manninen oli veendunud, et ilma küllaldaste tagavaradeta on raske nende nähtuste levinemise piire määrata ning muuseumi suurtel tagavaradel on tõsine väärtus: Ei ole põhjust kaevata olemasolevate variantide ja dublettide paljususe üle! (Õunapuu 2001: 129). Ka G. Matto meenutused annavad selgema vastuse $\mathrm{Kr}$. Raua ja teiste kunstnike muuseumi algaastate kogumistöö valikuprintsiipidest.

Kunstnike kogumistöö keskendumine väiksemõõdulistele esemetele ja tekstiilile oli tingitud muuseumi algaastate ruumikitsikusest. Kitsad olud takistasid algul muuseumile suuremate esemete kogumist, mistõttu need märgiti vaid üles (ERM EA varia 16: 2). G. Matto järgi polnud alguses muuseumil mingeid ruume ning esemeid hoiti kuni 1911. aasta alguseni Kr. Raua korteris ja maalimiskursuste ruumides, O. Kallase korteris, K. E. Söödi trükikoja ruumides: Niisugune asjaolu oli ka üheks põhjuseks miks algul väga tagasihoidlik oldi suuremate esemete kogumisega (Matto, EA varia 16: 2; Matto 1965, EA varia 16: 7). Kogujatel soovitati vaid üles märkida esemete asukohad, sest puutelgedega vankrit, atra, karuäket, rehepeksu tampi või vanaaegist veesõidukit pole ju võimalik paigutada voodi alla. Ruumipuuduse tõttu koosnesid esi- 
meste vanavarakorjajate O. Kallase, Kr. Raua ja A. Laikmaa kogud puhtal kujul rõivastusesemetest, mille hulka harvasti oli eksinud mõni puust õllekann (Matto, EA varia 16: 2). Hiljem, kui ERM sai ajutised ruumid, toodi sinna Õpetatud Eesti Seltsist kapid setu ja saarte ülikondadega, samuti tulid siia värskelt kogutud asjad, mis kontrolliti ja pakiti kastidesse, suuremad puuesemed köideti kimpudesse. Kahetoalise korteri saamine Vanemuise ruumides oli väga suure tähtsusega, sest esemetel oli nüüd olemas kindel koht, kus oli võimalik ka vanavarakogujaid vastu võtta ja välja saata ning kohalesaabunud esemeid kastides säilitada (Matto, EA varia 16: 2). Et muuseum kuulus alguses vaid ERMi Seltsile, siis puudus G. Matto järgi muuseumil laiema seltskonna toetus. Eesti rahva muuseumiks hakkas ta muutuma 1910. aasta lõpul ja eriti 1911. aasta algul: Sel ajal kujunes eesti noortes, eriti üliõpilasnoortes, tõekspidamine, et muuseum on meile lähedane, ta on ju meie oma ettevõte, tema eduks peame tööd tegema, see on meie aukohus (Matto, EA varia 16: 4-5).

20. sajandi alguse kunstnikele võib tõepoolest etteheiteid teha, et kogumata jäi suur hulk argiesemeid ja tööriistu ning keskenduti peamiselt hävimisohus meisterlike käsitöönäidete päästmisele. G. Matto meenutab, et Kr. Raud ei olnud kõigi kogutud esemete ja ornamentidega rahul. Ta ei kasutanud küll sõna 'inetu', kuid pidas neid 'maitsetuks' ja teatas saksapäraselt: Ah, see on nii

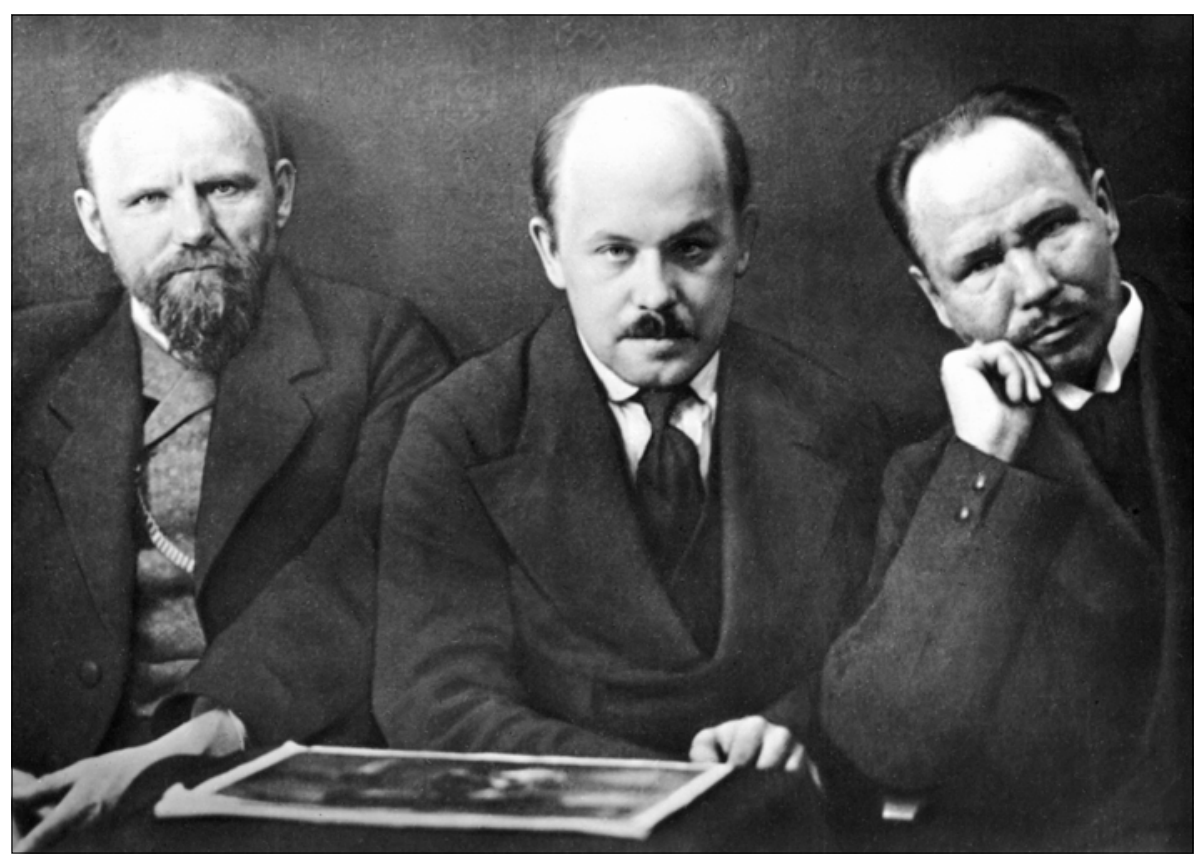

Ants Laikmaa, Nikolai Triik ja Kristjan Raud. "Uudse” pk. Johannes ja Peeter Parikase foto. KM EKLA A-118:147. 
konventsionell! (ERM EA varia 16: 11). Kunstnikele on ette heidetud ka liigset keskendumist esemete kunstilisele ilule, kuid samas näiteks I. Manninen (1923) tunnustab suuri mustrite kogusid (sh õllekannude kogu), sest nende abil võib juba kindlama ülevaate saada (Õunapuu 2001: 126). Silmapaistvate tunnustega esemete kogumise põhjus oli kindlasti seotud kogumistööd juhtinud kunstnike professionaalse ettevalmistusega. Kunstnikud nägid selgelt rahvaloomingu variatiivsust, mistõttu eriliste ja kunstiliselt väärtuslike artefaktide kogumisele keskendumine aitas päästa kvaliteetsed loomenäidised hävinguohust. Tuleb ka arvestada, et disain ja funktsionaalsus ei kuulunud möödunud sajandi alguse eesti kunsti peamisesse teemaderingi ning ei olnud ka kogumistööd juhendanud kujutava kunstialase haridusega $\mathrm{Kr}$. Raua huvideväljas. Kr. Raua eesmärk oli päästa rahva looming ning ta püstitas kogumistööle silmnähtavalt omalaadse ja uuendusliku ülesande, mis lõi rahvakunstile kunsti kategooriates lähenedes uue tähenduse.

Eesti Rahva Muuseumi algaastate vanavara kogumise peamised ideoloogid Oskar Kallas ${ }^{5}$, Ants Laikmaa ${ }^{6}$ ja Kristjan Raud ${ }^{7}$ kirjutasid esemete päästmiseks ja muuseumi mõtte selgitamiseks hulgaliselt üleskutseid. ${ }^{8} \mathrm{Kr}$. Raua ja A. Laikmaa kogumistöö oli seotud ka nende pedagoogitööga, sest mõlemad innustasid noori kunstnikke ja kunstiõpilasi vanavara kogumisest osa võtma ning suurem osa tuntud kunstnikke ja kultuuritegelasi käis vähemalt korra külades muuseumile esemeid kogumas. Hilja Silla andmetel võttis kogumisaktsioonidest aastail 1909-1923 osa üle poolesaja kunstniku ja kunstiõpilase. Kr. Raua ja A. Laikmaa kõrval ka Nikolai Triik, Oskar Kallis, Jaan Koort, Aleksander Tassa, Konrad Mägi, Aleksander Uurits, Eduard Taska, Hanno Kompus, Juuli Suits, Oskar Karin, Voldemar Kangro-Pool, August Pulst, Gustav Mootse, Jaan Grünberg, Joosep Kliiman, August Meibaum, Eduard Oras, Johannes Võerahansu, Voldemar Haas, Marta Kangro-Pool, Juhan Nõmmik, Aleksander Promet, Johannes Jans jpt (Sild 1972: 68). Kogumistöö tulemusel korjatud suurepärane esemekogu on hindamatu väärtusega pärandus kunstnikele ja teadlastele, kuid annab samas ka hea ülevaate kogujate eelistustest. Kogujate töö ei olnud kerge, sest vanavara korjajaid peeti külades tihti 'võõra vara himustajateks' ja 'harjuskiteks' ning õnnestumiste kõrval tuli ületada ka mitmeid raskusi (Sild 1972: 68). Eriti Kr. Raud oli pahane, et välismaised uurijad viivad parimad esemenäited Eestist välja (Kangro-Pool 1961: 74). ERM on tänaseks välja andnud kolm vanavarakogujate aruannet (Kallas 2006; Pulst 2006; Triik \& Pedak 2007), kuid artiklit kirjutades toetun isiklikule arhiivitööle ja korjajate käsikirjaliste dokumentide läbivaatusele. Kirjutajate käekiri ja mitmesugused "kritseldused" muudavad allikmaterjali kõnekaks ning aitavad mõista kohapeal kogetut, võrrelda välitöökogemusi ja kõrvutada sajanditaguste korjajate kirjalikke märkmeid kunstniku kogemustega. 
Vanu esemeid kogunud kunstnike tähelepanekuid ja emotsioone võrreldes on tähelepanuväärne Alutaguse kandis 1888. aastal rahvaluulet kogunud O. Kallase poolt värvikalt kirjeldatud kogemused, täpsemalt mure, et isegi kümne aastaga võivad inimesed unustada väga suure hulga repertuaarist ning kirjaoskuse arenedes mälu kaob:

Kuigi rahva vana eluolu on kadunud, ei ole "muinaskultuur" siiski hävinenud, sest "kui vanemad hakkasid oma laulusid unustama, siis olid lapsed juba kirjaoskajad ja tähendasid paberile, mida mälu enam edasi ei viinud." Seda muudatust oleksite ühes minuga tähele võinud panna, kui ühes minuga ühe sammu, ühe rahvapõlve tagasi oleksite astunud; veel 1888 kirjutasime ühes kaaslasega paaris Põhja-Eesti kihelkonnas umbes kuuaja jooksul üles 18000 rida rahvalaulu; sealtsamast saadi umbes aastakümne pärast ainult paartuhat rida ja nüüd on vast ainult erandina mõni laul säilinud (EKLA f 186, $\mathrm{m}$ 81: 17, O. Kallas, kõne Kalevala peol 1.03.1935, lk 1/3).

O. Kallas rõhutas, et uue elu ees folkloor hävib: See ja vanaluule vanausu kadumine võib kurb olla kuulda ainult - folkloristile, kuid on rõõmustav rahva sõbrale; rahva sisemine elu ja vaimline silmaruum laienevad-ja selle eest võib ka folklore maksta." (samas lk 1/17).

O. Kallase käsikiri 1888. aasta suve kogumisretkest annab ülevaate, kui raskeks osutusid rahvaluulekogujate elamis- ja kogumistingimused. Öömaja otsiti koolmeistrite juurest, sest taludes oli lutikaid, kärbseid, sääski ja haigusi (EKLA f 186, m 79: 27 lk 34-35). Kohalikud koolmeistrid, kes viitsisid kogujaid aidata ning viisid neid laulikute juurde, meelitasivad nende meeli mahedaks, et inimeste keelepaelad avaneksid, usaldus tekiks (samas lk 19). Elavalt kirjeldas O. Kallas, kui raske oli külaelanikke rahvaluule kogujaid usaldama ja aitama meelitada. Tuli õppida teatud kavalusi kasutama, sest muidu laulikute südamed ja suud ei avanenud (samas lk 22). Mõnda külla oli kogujatest ka ette joutud teatada ning inimesed olid nende hirmsate inimeste eest metsa peitu pugenud. Kõige enam kahju olid vanavara korjamisele teinud Vennastekoguduse liikmed ning laulikud kartsid laulude ettekandmisega pattu teha (samas lk 23-24). Imestati, miks kogujad oma aega ja raha kulutavad ning kardeti, et laulud lastakse trükkida ja kogujad saavad nende eest palju raha. Suureks takistuseks kujunesid ka võõraste peenemad riided, mistõttu neid peeti saksa värki meesteks (samas lk 25). Kardeti ka kroonu karistust ega tahetud avalikult vanu laule laulda, et mitte teiste naeru alla sattuda. O. Kallas: Nooremal rahwal on raamatust õpitud laulud ja naeravad wanemate üle, kes weel regiwärsiga juhtuvad walgeette tulema. Ka kogujate vastu oli umbusk suur, et äkki ikka naeravad laulja üle. O. Kallas kirjeldab, et mõnikord aitas kavalus ja korjajatel oli võimalik teisest toast läbi ukseprao kuuldud laulud 
üles kirjutada, sest laulik oma nägu laulmise ajal näidata ei tahtnud (samas lk 25-26).

Laulikutele ei tohtinud mingil juhul ka näidata, et juba palju laule on korjatud ning kasutati taktikat, et pooltgi sõna ei ole saanud, vaid alles üsna hakatuses olime - siis võis loota, et mõni ometi heast südamest paar laulukest kinkis (samas lk 26).

ERMi käsikirjaliste kogude põhjal selgub, et 20. sajandi alguse esemelise pärandi kogujate märkmed sarnanevad O. Kallase tähelepanekutega ning kogumispäevikute andmed võimaldavad jälgida nii nende isiklikke läbielamisi kui ka selgitada esemete hävimisprotsessi põhjuseid. Kogumispäevikud ja aruanded kirjeldavad mitmeid tähelepanekuid, raskusi, pettumusi, õnnestumisi, ohtusid ja kohalikega suhtlemise raskusi. Selgub, et kogujate võimed olid inimestega suhtlemisel erinevad ja tihti sõltus töö tulemuslikkus isiklikest veenmisoskustest. Oskar Kallas kirjeldab: Westasime wanamooridega enne paar tundi juttu sinati kantust ja kurjavaimu kawalusest, tublidest talu taatidest ja saadana sala wõrkudest, - saani siis sel wiisil südame ukse prauli saanud, siis julgesime juba pea ukse wahelt sisse susta ja õige tahtmisega wälja tulla (EKLA f 186, m 79: 27, lk 22).

Kunstnik Nikolai Triik ja Eduard Pedak kirjutavad 1909. aasta kogumispäevikus:

Nimetamata ei või jätta, et kõigel meie reisi ajal igal pool söögi alla ja peale "napsud" tehti, liig joomist peeti aga hukkamõistmise vääriliseks. Enamasti mitte söögi ajal tuleb peremees, pudel hõlma all ja küsib ettevaatlikult ääri veeri mööda, kas noored herrad napsu võtavad. Eitava vastuse juures võtab ise lõnksu, viib pudeli tagasi ja tuleb ohates tuppa. Jutu lõng on katkenud ja asi ei edene. Vaene vanavarakorjaja läheb vist sealt siis tühja kättega minema (ERM TAp 1, TAp 2).

A. Laikmaa kirjutab oma kogemuse põhjal:

Enam peaks suveks väljasaadetud korjajaid valima. Igat linna noorsaksa, kes maarahva hinge ei tunne, ei peaks välja saatma. Vanavara pole harilik kaup, mille ostjat talupoeg ootab. Osalt on ta "tühi rämps" ja "koli", osalt "kallis” vanematelt jäänud "mälestus". Ei tulda ka igalpool korjajatele lahkelt vastu, sest ei tunta, mis "asjamehed" nad õieti on ja "asjamehed" ei oska ka endid tutvustada ega lähendada. Kus aga osatakse, suhtutakse suurepäraselt (Laikmaa 2001: 228-229).

Kogumispäevikud on ka erineva sisulise ja kujundusliku kvaliteediga, mõnda on lihtsalt huvitav lugeda (TAp 65 - tore päevik: päevaraamat, korjaja Georg Gross, Ambla khk 1913) või joonistusi vaadata, (näiteks joonised seelikutriipudest, vöö- ja kindakirjadest: EJ 44 Võnnu ornamendid jm G. Mooste 1912). 
Eesti Rahva Muuseumile koguti esemed ükshaaval küladest ja taludest kokku ning kunstnike osa teiste eesti humanitaaride ning muude erialade esindajate kõrval oli vanavara päästmisel väga suur (Laikmaa kiri Kristjan Rauale, EKLA f 221, m 2: 19, 10/17). Kuid 20. sajandi alguse kogumisaruannetes kurdetakse, et rahvas ei taha esemeid ära anda ja saamata jäänud asjad on märgitud üles (TAp 182: 12). Raske oli ka vanu asju leida (samas: 13), sest neid polnud enam (samas: 14). Märgitakse, et rahvas on küll kaunis vastutulelik, kuid asju ei taha anda, ehk ainult vähem väärtuslikke: Läbi korjatud külad: 20 küla, asju saadud 33 nummert (samas: 48). Selgub, et kuigi enamasti saadi asjad muuseumile kingituseks, jäeti osa ka andmata, sest inimesed tahtsid neid kui mälestusi hoida (G. Matto "Aruanne ainelise vanavara korjamise üle Halliste kihelkonnas jaanikuul 1911": 2; TAp 40. "Vanavara korjamisel Muhus, Keinaste ja Kese saartel 1912". Paul Ruus: 7). Korjamine tuli mõnikord enneaegselt lõpetada, sest koguja sai kõhutõve (TAp 182: 48). Selgub, et korjajatel pole ka aega pikemalt kogumistööga tegeleda ning neid liitub ja lahkub kogumisgrupist (H. Weski: 3. juunil ei kirjutatud - oli muud õiendamisi (TAp 161: 17)). Mõned kogujad on loetlenud talusid ning üles märkinud neist kogutud esemed, kuid kirjutised on emotsioonitud ja neid ei ole huvitav lugeda (vt nt TAp 161. "Päevaraamat III Lüganuse khk vanavara korjamisel 1915. a. suvel, korjajad L. Subka, H. Weski, A. Kikajan, neiu Wälbe”). Kogumisretkel käinud G. Matto kirjeldab aga värvikalt, et kuigi mitmel pool võeti korjajaid külas hästi vastu (G. Matto "Aruanne ainelise vanavara korjamise üle Halliste kihelkonnas jaanikuul 1911": 4), saadi mõnel pool pereema käest eeskujuliselt sõimata ning külvati kohe kõiksugu auunimetustega rikkalikult üle: "Kuradi Wargad" ja "Tartu kaabakud" aina lendasivad mis lust. "Vai Tartust tulewe sija wargile” (samas: 3). Muret tegi ka see, et mitmed eraisikud olid enne juba asju kogumas käinud ning eriti vöid oli mõisatesse ostetud ja ka eraisikud enesele korjanud. G. Matto: Nägin ise Halliste kiriku ligidal ühes jõukamas talus vanaaegsete vöödega kaetud suure sohva. Samuti öeldi sääl kaks sarnast tooli olevat. Just vanade laiade vööde poolest leidsime Halliste tõesti tühjakskorjatud olevat. (samas: 4). Märgitakse ka, et igal pool söögi alla ja peale "napsud” tehti, kuigi liigjoomist peeti hukkamõistmise vääriliseks: Viina meie ühes ei kannud ja vist ei oleks see midagi aidanud. Igal pool võeti viinatagi hästi vastu, muud kui ise pidid viina võtma (TAp 1, TAp 2 "N. Triiki ja Ed. Pedaku aruanne ainelise vanavara korjamise üle"; Suvel 1909. ainelise vanavara korjamine - Iisaku khk, korjajad kunstnik N. Triik ja Ed. Pedak (üliõpilane) 22. juuni + Grau ja Uurits Kodaveresse: 6). Nähakse ka inimeste mustust ja vähest haridust ${ }^{9}$ ning ebausku ${ }^{\mathbf{1 0}}$.

Rahvariideid polevat ammu kantud ning vanaaegsed hooned ja tarberiistad on kõik kadunud (TAp 66. "Mõned täiendavad märkused minu vanavara korja- 
mise kohta 1913. a", A. Kasekamp. 21. jaanuaril 1914 tagantjärele kirjutatud: 1; TAp 40; "Vanavara korjamisel Muhus, Keinaste ja Kese saartel 1912." Paul Ruus: 2; TAp 4 Kehras 18.09.1910 "Aruanne ERM heaks asjade korjamise üle Kolga randades, Kuusalu kihelkonnas 1910. a. suvel": 2). Ehted, eriti hõbesõled ja preesid on moest läinud ja juutidele ära müüdud või linnas ümber vahetatud. Vanad asjad mõtlematult purustatud ja hävitatud ning kui oleks varem teadnud, oleks alles hoitud (TAp 4 Kehras 18.09.1910 "Aruanne ERM heaks asjade korjamise üle Kolga randades, Kuusalu kihelkonnas 1910. a. suvel": 2). Asju ei saada ka kuidagi omanikelt kätte, sest ühed lubavad neid pärast surma muuseumile anda, teised ei anna sellepärast, et need vanaisa või vanaema pärandus olla või nõutakse asjade eest liiga suurt hinda (TAp 66: 1). Huvitav on ka kohalike soov korjajatest ruttu vabaneda ning teise talusse saata, mille peapõhjuseks korjajad ise arvasid, et rahvas ei jäksa rahva muuseumi mõttest ega selle tähtsusest aru saada. A. Kasekamp: Mina käisin Jüris 342 peret ja sauna läbi, kuid täielikku arusaamist rahva muuseumi üle leidsin umbes 20 perest. (TAp 66: 2). Leidub ka juhtum (A. Kasekamp), kus saunaeit ähvarduseks vembla võttis: Mis siis kaltsukorjajad teevad, kuijuba niisugused herrad kaltsusid hakkavad korjama? Silmapilk kasi minema! (TAp 66: 3). Kogujad kirjutavad Muhumaalt: Öömaja lubab iga peremees võõrale häämeelega. Kuid ilma rahata ei saa nende käest mitte midagi, mitte nööpnõelagi, kõhutäiest ja veel kingitustest muuseumile rääkimata. Muuseumist ei olnud neil muidugi aimugi (TAp 40: 2). Kuid leidub ka piirkondi, kus vanavara heameelega muuseumile kingiti, sest ajalehtede kaudu on muuseumi tööst juba teada saadud (TAp 82: 1).

Esemekogujaid saadeti küladesse koos teiste elualade professionaalide ja üliõpilastega. Kuna Kr. Raud juhendas isiklikult kõiki kogumistööle suunduvaid esemelise vanavara korjajaid ning oli ka ise korduvalt külades käinud, oli tal selge ülevaade, kuidas külades elati ja milliseid raskusi korjajad kohapeal kogesid. Nii mõnigi kord tuli aidata O. Kallasele pahastelt külaelanikelt laekunud kaebusi juhatuses lahendada ning Kr. Raud enamasti kaitses korjajaid (EA varia 16: 13). Eesti Kirjandusmuuseumi ja Eesti Rahva Muuseumi arhiivides leiduvad käsikirjalised allikaid ja fotokogud (Fr. Kohtitsky ja J. Pääsuke) väärivad kunstnike jätkuvat uurimistööd, sest kuigi Kr. Raua elutööst ja vanavara kogumisest on ilmunud erinevatele sihtrühmadele suunatud artikleid, monograafiaid, uurimusi jm kirjutisi, ei suuda nende lugemine korvata kunstitaustaga lugeja elamust, mida võimaldab tutvumine originaaldokumentidega. On selge, et külades korjamistööl osalenud kunstnikele avaldas sügavat emotsionaalset mõju kohapeal nähtud olukord ning isiklikud kogemused avaldusid ka nende kogumispäevikutes ja loomingus. Inimesi ja tollast kultuurimaastikku tundma õppides kujunes paljuski kunstnike arvamus oma rahvast, ajaloost ja tulevikuvõimalustest. 


\section{Kunstnik Kristjan Raud - mõtleja, ärataja, muretseja}

Üle kahekümne aasta pedagoogilist ja muuseumitööd pidurdas oluliselt Kristjan Raua loomingulist tegevust. Kui Kr. Raud 1913. aastal Tallinna kolis, jätkus tema tegevus Tallinnas moodustatud Eesti Rahva Muuseumi osakonnas, millest hiljem kujunes Tallinna Eesti Muuseum. Kr. Raud valiti 1919. aastal ministeeriumi kunsti ja muinsusasjade korraldajaks (EKLA f 219, m 131: 9: 6). Ta kurtis, et ei suuda kõiki temal lasuvaid vastutusrikkaid kohustusi täita: Meie ei suuda küllalt nobedad ja hoolsad olla rahva endiste loomingute päästmisel ja nende nii iseäraliste hingeliste väärtuste tagasitoomisel rahva hulka, kus need jälle uuesti produktiivseks muutuvad (Raua kiri K. E: Söödile 23. XII 1926, kirjandusmuuseumi käsikirjade osakond, fond 173). Kunstnik rõhutas, et meie algupära tuntakse väga vähe, sellest

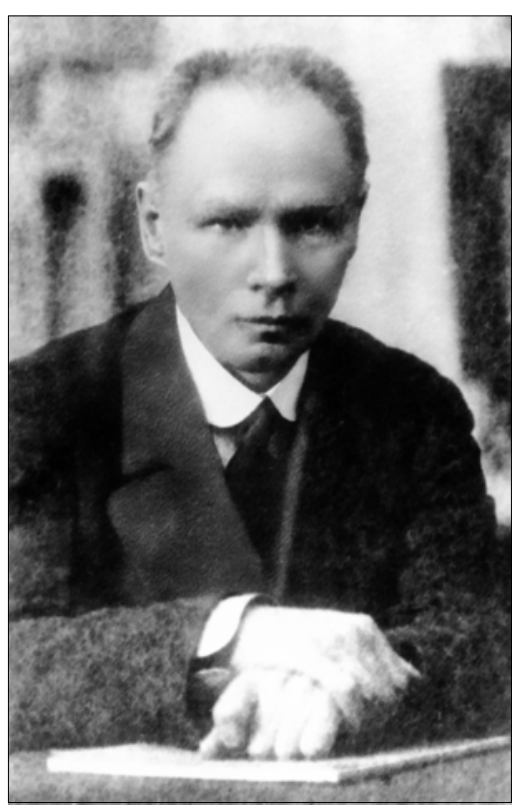

Kristjan Raud. Johannes ja Peeter Parikase foto. KM EKLA A-181:2175. kõneldakse ükskõikselt ega hinnata vääriliselt (EKLA f 74, sinine märkmik: 26). Ta oli veendunud, et Eestirahva omapära on kadumisel: Peaksime enestele selgeks tegema mis meie selle läbi kautame. Ma ei liialda kui ütlen, meie kautame rahva (samas: 22).

Kristjan Rauda isiklikult huvitanud teemad, mis olid otseselt seotud tema loominguga, tingisid tema kogumistöö eesmärkide kujunemise ja muutumise. Kunstimuuseumi kogud ning Mai Levini koostatud värskeim ülevaade Kr. Raua loomingust (vt nt Raua loomingust rahvaluule ja Kalevipoja ainetel Levin 2006: 158-198) annavad võimaluse jälgida kunstniku visandites ja joonistustes toimunud arenguid ning näha, miks muutuvad informantidelt ja kirjasaatjatelt saadud teated esemelisest pärimusest olulisemaks. G. Matto järgi olid kuni 1913. aastani peaaegu kõik muuseumi üleskutsed kirjutatud Kr. Raua poolt, et kutsuda varakogumisele võimalikult palju abijõudusid (EA varia 16: 9), kuid alates 1913. aastast jäi üleskutsete kirjutamine G. Matto hooleks, sest Kr. Raual polnud selleks enam aega. Kunstniku huvi oli uute loomingueesmärkide tõttu juba selgelt muutunud: Ta hakkas nü̈̈d üles tõstma uusi küsimusi, millistele vanavarakogujad kogumise juures katsuksid leida vastuseid. G. Matto peab silmas Kr. Raua kirjutist: "Missugused olid meie muinasloolised olevused?” (Postimees nr 113, 18/31 V 1913) ning hiljem ilmunud Kr. Raua kirjutisi, 
kus otsib vanavarale sisu (nt "Meie mälestusmärkidest" (Postimees nr 112, 1914); "Endised ehteasjad ja meie naisterahvas" (Postimees nr 124, 5/18 VI 1914); EA varia 16: 11). Selleks, et kujutada pärimust nii, nagu pärimusekandjad ise seda näevad, saatis Kr. Raud välja küsimustikke, et koguda materjali eesti mütoloogiliste olendite välimuse kohta (nt EKLA f 221, m 5: 19, lk 2; lk 22-26). Kr. Raud koostas saadud materjali põhjal aruanded (EKLA f 221, m 5: 19 ja EKLA f 157, m 14: 27) ja edastas need J. W. Veskile (nt EKLA f 157, m 13: 3). Kirjasaatjate abi kasutades lõi Kr. Raud kunstielus omamoodi pretsedendi, sest elava pärimuse kohta informantidelt ja kirjasaatjatelt küsimustike vastustena laekunud kirjalikke teateid polnud eesti kunstis keegi varem sidunud professionaalse kunstiprotsessi vajadustega.

Kui kogumistöö algaastatel uuris kunstnik esemeid ja mustreid, siis nüüd oli tekkinud vajadus uue informatsiooni järele. Kr. Raud vajas hädasti teateid informantidelt, sest soovis toetuda elavale pärimusele, et oma loomingus muistsete lugude tegelasi tõepäraselt kujutada ( Mai Levin peab 1919 eksponeeritud söemaali "Kalmuneid" üheks esimeseks Kristjan Raua Kalevipoja-stiilis valminud loomingu küpseks tööks (Levin 2006: 158)). Kirjasaatjatelt laekunud vastustega oli ta ühest küljest väga rahul, kuid muretses, et ilusaid organilisi tervikuid enam ei ole rahva hulgas leida. Kr. Raud arvas siiski, et fragmentidega tuleb leppida ning rõomustas, et korjandusest kogunes rohkelt vajalikke teateid: Ju nü̈̈d oleks võimalik käesoleva materjali varal terve rea olendite isikuid, nagu need meie esivanemate meelest elasid, kaunis teravates piirjoontes kindlaks teha. Kr. Raua käsikirjast selgub, et teiste hulgas leidub kirjasaatjaid, kes on kunstniku soovidest õieti aru on saanud ja ei unustanud läkitada kirjapandud lugudes ka nähtuste ja olevuste välimuse kirjeldusi. Ta oleks soovinud, et ka vanavara korjajad oleksid vaevaks võtnud sama teha (trükitud kujul aruanne EKLA f 157, m 14: 27 - "Missugused olid meie muinasolevused? Kolmas aruanne korjatud ainete kohta").

Kui Kr. Raud Tallinnasse kolis, sai ta muinasolendite kohta jätkuvalt laekuvaid teateid J. V. Veski saadetiste kaudu (EKLA f 126, m 3: 2). Koostöö oma aja silmapaistvate rahvaluule uurijatega mõjutas kindlasti ühest küljest Kr. Raua püüdlusi kujutada pärimust tõepäraselt ja täpselt (EKLA f 221, m 5: 19). Samas hoidus ta aga liigsest eeskujudesse klammerdumisest ning üritas tabada oma loomingus pärimusele iseloomulikku tunnet, mida tekitasid kujutlusvõime ja isikupärane kunstniku käekiri. Loomingus püüdis Kr. Raud anda ununema kippuvaid tekste edasi kunsti vahenditega, et säilitada rahvasuust kogutud teadete tähendusi ja väljendada kogutud teadete mõjul tekkinud sügavaid emotsioone. Kr. Raud usaldas siin uurijate arvamusi ning küsis näiteks M. J. Eisenilt korrigeerivat abi ja nõu noorele vabariigile "põhja-kotka" vappi kujundades, sest püüdis kavandi seletuskirja koostamisel leida tuge kunstnikutunde ja sümbolite valiku õigustamiseks: 
Kristjan Raua kiri Karl Eduard Söödile, 5. juuni 1915. EKLA, f 173 m 16: 1.

Olen vapi põhisümboliks "kotka" valinud, olevuse keda rahvas ju muinaslugudes tarvitas kõrget müsilist jõudu kehastava kujuna. Nii siis rahvast enesest vastu võetud, omaks tunnistatud ja santsioneeritud embleem.[---] Tõi ju tema omal tiivul meile Kalevi, Eesti rahva esimese kaitsja, suure korraldaja ja riigi asutaja. Mõnes laulus nimetatakse "põhja-kotkast”-kurjaks linnuks, kuid sõna "kuri" tähendab siin võimast, kardetavat, äravõitmatut ja kaitsvat (EKLA f 25, m 12: 28).

Kuna kunstnik-kogujana oli ta tuttav elava ja mahlaka rahvapärase sõnavara ning juturepertuaariga, ei olnud ta hiljem rahul ka trükitud väljaannetega, kus rahvasuust pärinevaid tekste oli mahlata ja vereta ümberjutustusteks muudetud. Kirjas K. E. Söödile (27. 01. 1927) pahandab K. Raud:

Eiseni "Eesti muistsed vägimehed" on labased, kuivad järeljutustused, täiesti mahlata ja vereta. Muinaslood on harilikult täis helinat, ladusat lihtsust, mõnu, naiivsust ja ootamatusi. Neist ridadest otsid seda kõike asjata. Koputa laua pihta ja sinule vastab hingeta hääl. Nii on mainitud lood (EKLA f 173, m 16:1).

Kr. Raud oli kriitiline ka 1935. aastal ilmunud Kalevipoja ${ }^{11}$ illustratsioonide suhtes, sest liiga kiire tähtajaga valminud tellimustöö tulemuste tõttu tegi ta endalegi korduvalt karme etteheiteid (nt kirjavahetus Söödiga, EKLA f 173, m 16:1, lk 43/79).

Kristjan Raua kunstikreedo klammerdu kodumaasse, seal on sinu võimete juured (ERM EA varia 16: 11) oli peamiselt kantud kunstniku veendumusest, et ka üht väikest rahvast võib tõsises mõttes suureks nimetada, kui tema liikmed maailmale midagi positiivset ja rikastavat loovad, midagi ülendavat pakkuda suudavad. Selleks peab sarnaseid inimesi palju olema ning neid peab juurde sündima, rahvas peab terve ja "kulutamata" olema ning neil peab "alg- 
energiaid" piisavalt olema, et loomulik ja vaimsusega tervik moodustada (EKLA f 74, sinine märkmik: 23). Ta nägi, et kaotades huvi algupära ja traditsioonide vastu kaotab rahvas oma vaimsuse ja väärikuse, mis teiste kultuurrahvaste (kreeklased, jaapanlased, norrakad) puhul on aidanud oma kultuurist parandavaid ja ülesehitavaid jõudusid leida ning Euroopa kultuurile midagi olulist pakkuda: Kes teadis enne Norrast kui see ilmale Ipseni, Griigi, Nordenskjoldi, Mungi, Knut Hamsuni jt polnud annud? (EKLA f 74, sinine märkmik: 24-25). Raud püüdis oma märkmetes põhjendada, miks leige suhtumine väikese rahva omapära vastu on jätnud unarusse kultuurile nii olulise järjepidevuse.

\section{Rahvakunst ja professionaalne kunst}

20. sajandi alguses toimus elav ja terav arutelu rahvakunsti üle ning sajandi esimesel poolel kujunesid välja ka mitmed hoiakud, mis ühelt poolt toetusid professionaalse kunstiõpetuse ja külades tehtud kogumistöö kaudu loodud mõjusale õppemeetodile, kuid teisalt on kunstnikud ka ise toetanud ja tootnud praegugi kehtivaid stereotüüpseid arusaamu. 20. sajandi alguses toimus mitme silmapaistva kunstniku, Noor Eesti rühmitusega seotud kultuuritegelaste ja poliitikute vahel elav diskussioon pärimuse koha ja rolli mõtestamiseks uuel sajandil ning muutunud kultuurikeskkonnas. Arvamused jagunesid põhimõtteliselt kaheks. Üksteisele heideti ette talupojakultuuri ja vanade väärtuste hülgamist või liigset romantiseerimist ning halvustati talupojakunstist inspireeritud professionaalse kunsti rahvuslikku piiratust. Nii mõnigi silmapaistev kunstnik arvas, et eesti kunst peab püüdlema nö Euroopa kooli tasemele ning vanavarale toetuv kunst ei suuda seda taset saavutada.

Sajandialguse kunstnikud Nikolai Triik, Aleksander Uurits, Oskar Kallis, Jaan Koort, Konrad Mägi, Aleksander Tassa, kes käisid ka ise külades vanavara korjamas, et soome, norra ja vene kunstnike eeskujul rahvakunstist inspiratsiooni leida, püüdsid siduda seda kõige vahetumalt oma kaasajaga (Pihlak 1969: 54). Eevi Pihlak märgib, et peaaegu kõik eesti kunstnikud olid 20. sajandi algul veendunud, et eesti vana rahvakunst on allikas, kust tuleb ammutada loominguks inspiratsiooni. Õhinaga kujutasid rahvamuistendite ja eepose teemasid Kr. Raua kõval ka N. Triik, A. Uurits, O. Kallis, A. Promet (Pihlak 1970a: 53). Kuid näiteks Jaan Koort oli veendunud, et kunstnikud ei vaja labakindaid ja õllekappu, sest kunstnikel on jõudu ja ideid ilma nendetagi (Pert 1936; vt nt Gens 1964: 90) ning protesteeris selle vastu, et talupojakunst muutuks ainsaks eesti kunsti inspiratsiooniallikaks. J. Koorti arvates on iga rahva kunst rahvuslik, sest kunstnik on sama hingega mis rahvaski. Ta kirjutas: Meil on ainult teatud hingeelu ja aimdus, et meie rahva hinges ikka midagi 
peitub, aga kuidas seda kunsti teel edasi anda, see on suur küsimus (Kirme 1989: 67). Kunst ei tunne rahvust ning eesti rahvuslikul kunstil (vöökirjadel ja ornamentikal) on ainult möödaminev tähtsus (Kirme 1989: 90).

J. Koort iseloomustas kahte vastandlikku leeri järgmiselt:

Ühelt poolt jäädi peatuma vanavara juurde, tunnistades seda meie tuleviku kultuuri ainukeseks inspiratsiooni ja eeskujude allikaks (Kr. Raud, A. Promet), teiselt poolt tehti hüpe 'Euroopasse', äärmiste 'ismide' juurde, kõigest kodumaalisest täiesti lahti üteldes (A. Vabbe, J. Vahtra) (Koort 1926; vt Gens 1964: 117).

Gustav Suitsu üleskutse "Olgem eestlased, aga saagem ka europlasteks!" (vt nt Tiik 1972: 49) näitab selgelt, et uute avanendud võimaluste valguses tõusis haritlaste hulgas vajadus ületada kultuuriline enesessesulgumine ja areneda teiste euroopa rahvaste parimate saavutuste tasemele. Seetõttu oli ka loomulik, et oma loomingulisi püüdlusi kaitsti ning Suitsu põhjendused olid täiesti arusaadavad ja vajalikud: Tuleb otsida neid sihtisid ja vormisid, mille juurde meid ühest küljest meie rahva vaim, meie rahva loomulikud omadused ja vajadused, teiselt poolt euroopaline kultuur juhatab (Suits 1905: 3-19; vt nt Viiroja 1981: 46).

Noorem kunstnikepõlvkond vajas oma teed ja loomingulisi sihte, lugupeetud ning autoriteetsete vanema põlvkonna kunstnike Kristjan Raua ja Ants Laikmaa mõtted ning püüdlused said kohati ka päris ründava kriitika osaliseks. Eriti kujukalt iseloomustab sajandi alguskümnenditel toimunud diskussiooni August Alle, kes rõhutas, et temal on vähe usku selle uue eestipärase kunsti tulevikku, mida tahetakse üles ehitada vöökirjast, lehmasabakaika ornamentidest ja kamakäkist (Alle 1919). Kr. Raud ja A. Laikmaa olid aga veendunud, et esivanemad väljendasid oma loomingu kaudu iidseid vaimseid väärtusi, sügavaid tundeid ning argielu kogemusi, mida tasub kunsti vahenditega väljendada. Kr. Raud rõhutas, et 'moderni' ei saa tühjale tuulele ehitada, sest tugev tulevik toetub mineviku paremiku vundamendile (Kangro-Pool 1961: 61). Diskussioonidest, arvamustest ning kunstnike loomingulistest otsingutest on ilmunud mitmeid huvitavaid ülevaateid (nt Suits 1905: 3-19; Tuglas 1910; Koort 1911; Koort 1926; Gens 1959; Kangro-Pool 1961; Lamp, Viiroja, Pihlak, Sild kogumikus Kristjan Raud, Ants Laikmaa 1970; Viiroja 1981; Kirme 1999; Helme, Kangilaski 1999: 82-118; Laikmaa 2001), mistõttu neil pikemalt peatuda ei ole vajadust. Võib vaid lisada, et Kr. Raud ja A. Laikmaa olid oma veendumustes ja püüdlustes üldsuse silmis siiski vähemuses ning pidid 1920. aastatel taluma kaasaegsete naeruvääristavat suhtumist teemaderingi, mida nad ise südamest armastasid. 
Nimetatud kaks suunda kehtivad teatud määral ka tänases eesti kunstis ning eesti professionaalse kunstiõpetuse sidemed pärimusega ulatuvad ühtpidi tagasi eelmise sajandi alguses peetud diskussioonini, kuid teisalt toetuvad koostööle teadlaste ja muuseumitega. 20. sajandi alguse eesti kunsti suurkujude rolli tänase kunstiõppe ühe olulise suuna rajajatena enam täpselt aga ei mäletata. Tuleb siiski mainida, et tänu kunstnike panusele rahvakunsti kogude loomisel on tänastel kunstnikel hindamatu võimalus uurida ja analüüsida loometööks vajalikke allikaid, sest ilma $\mathrm{Kr}$. Raua ja A. Laikmaa ning nende õpilaste sekkumiseta oleks suurem osa haruldasest pärandist lihtsalt hävinenud. Sarnaselt J. Hurda juhitud rahvaluulekogumise aktsioonile suutsid kunstnikud äratada laiemat huvi kaduma hakanud esemelise pärandi vastu ning nende jõuline sekkumine võimaldas peatada kiirelt süvenevat hävimisprotsessi.

Kristjan Raud andis vanavarakogumise emotsioonist inspireerituna mitmeid suuniseid omapärase kohaliku loometöö mõistmiseks ja arendamiseks. Ta oli muu hulgas veendunud, et loomingu kaudu väljendati kõrgemaid tundeid:

Lihtsad helid äratavad meites igaviku tundmusi, lasevad midagi kõrgemat, tundmata aimata. Kui sarnased virgutused ja aimdused võimalikud on, siis on üks parem, täielikum ilm olemas, millest nad pärit... Kui me kasvada ja edasi ehitada tahame, siis küll ainult - oma põlise hää alusel (Raud 1911).

Mida Raud siin silmas peab? Mis on see parem ja täielikum ilm, mida kunstnik näeb ja meie ei märka? Kuidas saab ta väita, et asise argielu kõrval on midagi salapärast ja siiski hoomatavat, mis ei sobi kokku mõne hilisema arusaamaga rahvakunstist? Kas Kr. Raud peab siin silmas rikkalikku fantaasiamaailma, millest kõnelevad rahvaluule ja muistsed lood? Või hoopis aastasadu võõraste vallutajate meelevallas oma maa ja väärikuse kaotanud esivanemate luule ja loomingu kaudu väljendatud unistusi ja hingemaastikku? Või raske argielu kõrval pühakspeetud kombeid ja uskumusi säilitanud inimeste salajast ning nähtamatut peidupaika? Mis on see oma põline hä̈̈, millele ta nii suurt tähtsust omistab? Kas Kr. Raud kõneleb kunstist, puhtast südamest voolavast hää ja kenaduse tundest, millega ilu loodi?

Kristjan Raud jääb salapäraseks ning soovitab süveneda:

Ainult [---] vähesed, kes suudavad omil jalul püsida ja oma sisemist elu jätkata, jaksavad tungida möödunud aegade tuumani ja seda hingestatult ja orgaaniliset siduda nüüdisaja nõuetega. See nõuab iseseisvust, resoluutsust, vaba silmapiiri ja väsimatut otsimist (Raud 1938: 10). 
Süvenemine ja rahvakunsti tuumani jõudmine on tänastele noortele kunstnikele raske ülesanne mitmel põhjusel. Ants Viirese järgi on 20. sajandi lõpuks teatud üleoleva suhtumise rahvakunsti põhjustanud nõukogude ajast pärit arusaam, et alates 19. sajandi lõpust kogutud rahvakunst on vaid esteetiliste väärtuste kogum. Ants Viirese arvates on Eesti avalikkus aktsepteerinud üldiselt levinud stereotüübi, et rahvakunst on lõpetatud ja minevikku vaibunud vana talupojakunst, kuid samas pole mingit teoreetilist mõttevahetust rahvakunsti olemuse ja piiride küsimuses Eestis toimunud (Viires 1992: 8). Rahvakunsti iseloomulike tunnustena on võetud arvesse peamiselt tarbeaspekti ja sellega seostuvat dekoratiivsust, kollektiivsust, traditsioonipidevust. Nõukogude Liidus ametliku ideoloogia püstitatud loosungiga sisult sotsialistlik, vormilt rahvuslik samastasti rahvakunst ja talupojakunst (samas: 11) ning rahvakunstiks peeti enda ja lähikeskkonna tarbeks kutselise koolituseta meistrite poolt käsitööna valmistatud ja esteetilist meelt rahuldavaid esemeid (samas: 15). A. Viirese poolt selgelt esile toodud stereotüüpseid arusaamu on aidanud säilitada muu hulgas ka professionaalne kunstiõpetus, sest rahvakunstist on kõneldud küll kui teatud liiki kunstiloomingust, mida kunstnikud on joonistuste, fotode ja muude dokumenteerimisvahenditega eri aegadel jäädvustanud, kuid konkreetsetest esemete autoritest, nende mõttemaailma kaardistamisest on õppetöös enamasti siiski hoidutud.

Kunstiüliõpilaste teadmiste puudulikkus ning pärimuskogukonnast võõrandumisega tekkinud mälukatkestus on osaliselt tingitud ka eelmise sajandi professionaalse kunstihariduse meetoditest. Oskar Raunam kirjutab, et vanavara kogumisega loodi baas eesti rahvakunsti kasutamisele kunstis ning $\mathrm{Kr}$. Raua tööle tugines hilisem eesti professionaalne tarbekunst (Raunam 1964: 910), kuid 20. sajandi alguses loodud õppevormi rajajate Ants Laikmaa ja Kristjan Raua eesmärgid muutusid aja jooksul tarbetuteks. Nende kunstipedagoogilised vaated seati juba siis tugeva kriitika alla, kui Kunstiakadeemia eelkäija (1912 asutatud Tallinna Eesti Kunstiseltsi initsiatiivil loodud kunstikursustest väljakasvanud Eesti esimene kunstiõppeasutus Riigi Kunsttööstuskool (1914)) asutamisel võeti eeskujuks parun Stieglitzi Tehnilise Joonistamise Keskõppeasutuse (alustas Peterburis tegevust 1879; ülevaade eesti kunstnike seotusest kooliga nt Tiina Nurk (Nurk 1972: 36-44; vt Toom 2004: 8, 15)) õppemeetodid. ${ }^{12}$ Kunsttööstuskooli õppeprogrammis domineeris pikka aega Stieglitzi koolist pärit stiilide eklektika, millesse O. Raunami sõnul oli vägivaldselt sisse põimitud eesti rahvusornament (Raunam 1964: 20). Rahvusliku käsitöö ornamente komponeeriti kunstikooli erinevate töökodade õppeülesannetes ning kompositsiooni ja stiliseerimise erialadel. Kooli kauaaegse direktori Voldemar Pätsi hinnangul püüdsid õpetajad-rakenduskunstnikud ja meister-instrukto- 
rid nii palju kui võimalik meie rahvuslisi iseärasusi kunstis ja tööstuses edendada ja ellu viia ning vastavalt koolitööd korraldada. Esimestel aastatel olid kooli juures avatud ainult teoreetilised klassid, kus õpetati ka joonistamist, maalimist ja voolimist. 1918. aastal loodi 5-aastane õppetöökodade süsteem (tikandus, dekoratsioon, voolimine, raamatuköitmine ja puuvoolimine olid esimesed eriained, millele lisandusid valitsuse toetusel graafika, trükitöö, litograafia, keraamika ja metalli-ning emailõppetöökojad). Saksa okupatsiooni ajal tõsteti kooli kursus 6-aastaseks ja sellest ajast töötas kool alam-ja ülemastmena. 1920. aastate lõpul muudeti välismaiste õppeasutuste eeskujul Kunsttööstuskooli veneaegset põhikirja, et see selgemalt väljendaks rakenduskunsti kooli ülesandeid ja võimalusi annaks kooli õpetust paenduvamaks ja meie oludele vastavaks muuta (Päts 1928). Tagantjärele võib tõdeda, et stiliseeritud rahvuslik ornament oli tarbekunsti dekoreerimise üks eriharu ning pärimusega seotud käsitöö sisulised otsingud polnud kunstnike seas populaarsed. Alles rahvusvaheliselt edukate kunstnike liitumine kooliga tõi uusi õppetöö suundi, mis tõrjusid välja Stieglitzi kooli vananenud õppeprogrammid (vt nt Kirme 1999: 139).

Helene Kuma järgi oli enne nõukogude okupatsiooni väljakujunenud kunst pärast sõda rangelt keelatud, mistõttu kunstiõpetuses oli lihtsam lähtuda otseselt rahvakunstist, selle ornamentidest, rahvaluulest, müütidest ja muistenditest. Rahvakunsti käidi joonistamas ja kogumas üle Eesti. Adamson-Eric (Erich Karl Hugo Adamson) vormistas näiteks Elgi Reemetsale Eesti Rahva Muuseumi kaudu suvepraktika raames tasulised komandeeringud rahvakunstipärandi korjamiseks-ostmiseks. Korjamistöö tulemusel kogunes juba esimese kolme aasta jooksul koolile väike muuseum 500 esemega, millest enamiku moodustasid tekstiilitööd (vaibad, tikandid, silmkoe-esemed), puunõud, mööbel (toolid) ja muud puuesemed. Kahjuks jaotati see kogu edaspidi laiali - osaliselt anti üle osakondadele, osaliselt kasutati natüürmortide joonistamiseks ja maalimiseks (Kuma 2001: 27). Kuid rahvakunsti teemadel toimus ka valulisi poliitilisi kokkupõrkeid. 1940. aastate lõpul, kui Adamson-Ericut hakati taga kiusama (vt nt Kirme 1999), kritiseeriti tema loomingut ning mõisteti ta tööde üle seltsimehelikku kohut, põrkusid H. Kuma sõnul kaks põhimõtteliselt vastandlikku seisukohta. Etnograafiamuuseumi töötajad eesotsas Salme Rikasega väitsid, et rahvakunst on kujunenud kindlal ajaloolisel epohhil, see olevat feodaalajastu tõekspidamiste väljendus vormis ja värvis. Seepärast tulevat rahvakunsti käsitleda kui stiililiselt lõplikult formeerunud eeskuju, mida ei tohi omavoliliselt muuta ega ümber töötada. Tarbekunstiinstituudi ja AdamsonEricu seisukoht oli, et rahvakunst on paljude aastasadade vältel kujunenud kunstilooming, mis on alalises muutumises ja arenemises niikaua, kui rahvas 
ise eksisteerib. Meieni säilinud rahvapärand on seega aabits, mille abil uus kunstnike põlvkond õpib end väljendama, luues selle toel uusi kompositsioone ning arendades vanu põlvest põlve pärandatud traditsioone. Diskussiooni lõppedes jäi kumbki pool oma arvamusele kindlaks (Kuma 2001: 27).

Järgneval perioodil muutus kunstiüliõpilaste külades toimuv kogumistöö ebavajalikuks. O. Raunami meenutusel asetati pearõhk nüüd muuseumite kogudele ning välitööde empiirilisele kogemusele ei pandud suurt rõhku (Raunam 1964: 15). Tarbekunstiõppes püüti toetuda rahvakunsti vormi ja dekoori sünteesimisele, korraldati suviseid mitmenädalasi etnograafilise joonistus-mõõdistuse õppepraktikaid ning erialane kompositsioon seoti rahvakunstiga (samas: 21). Professionaalsed kunstnikud ja kunstiülioopilased tegid koostööd muuseumite ja erinevate uurimisvaldkondade teadlastega, nende erialaseid joonistus-mõõdistusoskusi vajati esemelise kultuuri, arheoloogia, rahvusliku sisekujunduse ja arhitektuuri dokumenteerimisel (vt Kadri Viires kunstnike koostööst ERMi etnograafiliste kogudega ja etnograafiapraktikate eesmärkidest (Viires 2006: 103-107)). Kui varasemal perioodil olid silmapaistvamad õppejõud Mari Adamson ja Elgi Reemets, kes külades etnograafiapraktikaid läbi viisid, siis näiteks minu õpingute ajal 1980. aastatel toimusid etnograafiapraktikad juba suures osas muuseumite (sh teistest liiduvabariikidest pärit üliõpilaste kodumaal asuvate muuseumite) kogudes ning juhendatud õppeülesannete eesmärk oli enamasti sisutühi dekoreerimine, ornamenteerimine ja stiliseerimine. Muuseumite kogudes toimuvad etnograafiapraktikad olid siis juba üsna formaalsed ning küladesse viisid üliõpilasi veel vaid mõned üksikud õppejõud (teenekaimad neist olid Anu Raud ja Leila Pärtelpoeg ning unikaalse kunstiõppe meetodi loonud Kaljo Põllu, kes püüdis Paul Ariste ja teiste teadlaste toetusel ühendada kunstiloomingut ja teadust).

Kui muuseumieksponaadid on kunstniku silmis tummad dokumendid, siis elava pärimuskogukonna keskel avanevad esemete tegelikud seosed pärimusnähtustega ning välitöödel õpitakse tundma inimese ja tema loodud esemete sügavamaid vahekordi (Summatavet 2005: 42). Outi Turpeinen ütleb, et muuseum võib küll toetada mälu ning olla kunstnikele abivahendiks kultuurilise ja personaalse identiteedi moodustumisel, kuid on siiski kunstlik keskkond selleks, et esitleda algupärasest miljööst eraldatud esemeid (Turpeinen 1999: 22). Esemeid, mille valmistajatelt ja kandjatelt ei ole võimalik kunstnikke huvitavaid küsimusi välja selgitada, uuritakse vaid väliste näitajate alusel, registreeritakse valmistamisvõtteid, tehnikaid, lõikeid, vormi, kaunistuselemente ja ornamenti. Lood, mis selgitavad eseme funktsioone ning aitavad mõista artefakti valmistaja motiive ja valikuid, jäävad uuriva kunstniku eest varju. Esemelise pärandi 'tõlkide' rollis on kogude uurijad ja hoidjad, muuseumipe- 
dagoogid ja teadurid, kelle teadmistest kunstiüliõpilased otseselt lähtuvad. Kuid kunstniku üks võimsaimaid töövahendeid ja loomeprotsessi käivitajaid on uudishimu ja teadmistejanu kõrval ka emotsioon. Empaatiat ja tunnet (vaimustust, kurvastust, pettumust, üllatust jne) on raske vahendajate kaudu saavutada.

\section{Kunstnik välitöödel}

Helmi Üpruse, Elle Vunderi ja Ants Viirese poolt loodud alus rahvakunsti teaduslikule uurimisele ühelt poolt ning teisalt kunstnike empiirilise uurimistöö ja välitööde taas kasutusele võtmine võimaldavad kunstihariduse ning teaduse sidumise kaudu lahendada uue kohalikku identiteeti interpreteeriva kunsti ja disaini valdkonna arengu ees seisvaid takistusi. Kunstnik suundub välitööle nii uudishimu ajel kui ka uute teadmiste vajadusest, sest kunstnikku huvitavaid teateid pole informantidelt piisavalt kogutud. Näiteks Lauri Honko järgi suhtus varasem uurimine seletustesse sageli tõrjuvalt, pidades informandi seletusi kehvemaks kui tegelikke pärimusteoseid (Honko 1998: 59-60). Oma kogemuse põhjal võin väita, et esemelise pärandi loomingulisi tagamaid uurida soovides oleme enamasti hiljaks jäänud, kuid kunstnikke huvitavaid küsimusi on siiski osaliselt võimalik informantide käest koguda. 20. sajandi alguses käivitunud kunstnike kogumistöö taasavastamine ja rakendamine, mis oli oma ajas erakordselt visionäärne, aitab laiendada kunstiringkondade huvisfääre, paigata mälukaotust ja kultuurikatkestust. Uurides lähemalt esemelise pärandi loojate-autorite mõttemaailma, motiive ja loomingulise eneseväljenduse meetode, võib Kr. Raua ja kogumispäevikute märkmeid võrrelda ka kaasaegse kunstniku välitöökogemusega (vt Summatavet 2005; Summatavet 2006: 86-113). Kunstniku poolt läbiviidud välitööl ja süvaintervjuudel on keskne roll empiirilise kontakti loomisel uuritava esemelise kultuuriga ning ka Lauri Honko arvates ei tule uurida üksnes kindlapiirilisi artefakte, vaid keskenduda esemetega seotud tunnete, hinnangute ja käitumise kaardistamisele (Honko 1998: 63).

Välitöö võimaldab kunstnikul muu hulgas uurida nii esemete ideetasandit, vormi, valmistamist kui ka kasutust loomulikus keskkonnas. Kunstniku välitöö sarnaneb antropoloogi, etnoloogi ja etnograafi välitööga, sest ka kunstnik kogub uurimistööks vajalikku allikmaterjali, mida tuleb korrektselt dokumenteerida, litereerida ja vormistada. Kuid lisaks välitöö dokumentaalsele fikseerimisele ja kogutud andmete süstematiseerimisele töötab professionaalse ettevalmistusega loomingulise eriala uurija mitmete oluliste küsimuste ja probleemidega, mida kunstialaste eelteadmisteta on raske jälgida ja mõista. Stephen Scriveneri järgi võimaldavad reflektiivne praktika ja eksperimendid avalikus- 
tada ning luua väärtuslikke teooriaid, süsteeme ja norme, mis on allikaks teistele praktikutele või huvitatud osapooltele. Loomingulised professionaalid pakuvad asjade asemel näiteid, kujundeid, mõistmist ja strateegiaid, mida võivad kasutada teised praktikud (vt Scrivener 2006: 177). Ka Claude Lévi-Strauss ütleb, et kunstnik sarnaneb ühtaegu teadlase ja meistrimehega (Lévi-Strauss 2001: 46), kuid kunstnik valmistab käsitöölise vahenditega materiaalse objekti, mis on ka intellektuaalne objekt (samas). Kunstnik uurib pärimust, kuid teeb kogutud teadete põhjal midagi valmis. Selleks töötab ta kogutud andmed läbi, rakendab käsitöövõtteid oma eesmärkide saavutamiseks ning edastab uurimistulemusi ka teoste või esemete kaudu (Summatavet 2005: 24).

Kunstniku professionaalne ettevalmistus loob välitööle lisaväärtuse ning kunstnik on teiste esemeuurijatega võrreldes siin eelistatud olukorras. Välitööl rakenduvad erialased ja tehnilised oskused ning kunstnik-uurijale olulised töövahendid võimaldavad leida praktiliste kogemuste ja oskuste abil uusi teemasid, mida uurida. Kunstnik märkab välitöödel eelkõige pärimuskeskkonna ainukordsust, milline see välja näeb ning läheneb pärimusnähtustele eelkõige inimese kaudu. Kunstnik on 'oma kätega' esemete valmistaja, oskab artefakte 'lugeda' ning näeb detailselt ka eseme valmistamise protsessi. Pärimuse ja pärimuse kandjate 'portreteerimine' suuliste ja esemeliste kultuuritekstide kaudu loob uusi võimalusi informantide 'oma hääle' kuuldavaks ja nähtavaks tegemisel. Välitöö võimaldab loobuda olemasolevatest sterotüüpidest ning tuua esile uusi lähtekohti, millest koguda loome- ja uurimistööks uut inspiratsiooni. Välitööl kogetud emotsioonid ja uued tähelepanekud inspireerivad muu hulgas katsetama ka innovatiivseid kaasaegse kunsti ja disaini võimalusi (vt nt Summatavet 2006).

Esemed on teatud liiki mõtlemine ja suulise kultuuri kirjutamisoskus (vt nt Lotman 1999: 79-80, 85, 225). Visuaalses vormis esitatud tekstid 'kõnelevad' kogukonna poolt aktsepteeritud koodikeeles ning peegeldavad artefakti valmistanud kogukonna liikme loomeprotsessi (Summatavet 2005: 24). Petr Bogatyrev soovitab õppida lugema neid tekste samal viisil, kuidas õpime lugema ja mõistma erinevaid keeli (Bogatyrev 1971: 83). Bogatyrev näeb Moraavia slovaki rahvarõivaid uurides analoogi 'meie rõiva' ja emakeele vahel, mis sarnaselt emakeelega funktsioneerib kui multifunktsionaalne struktuur. Ta kirjutab, et emakeel ja 'meie rõivas' on meile kõige lähedasimad kõikidest keeltest ja rõivastest (samas: 96). Välitöö loob võimaluse uurida esemelise pärandi autorite vajaduste ja maitse-eelistuste kõrval ka konkreetset pärimuskeskkonda ning selles eksisteerivaid norme (vt Bogatyrev 1971: 85), kuid kunstnikule lisavad empiiriline kogemus ja kogutud uued teadmised ka loomingulist eneseväljendust võimendavaid impulsse. Kuigi artefakti kaudu edastatud sõnumid on ühelt poolt kogukonna sees jagatud normidega reguleeritud ja kok- 
kuleppelised teadmised (vt Bogatyrev 1971: 96-98, 102; Lehtinen 1984: 116; Lehtinen 1994a: 13; Lehtinen 1994b: 110; Lehtinen 1999: 7-8), võib artefakt mõnel puhul vahendada ka autorile ja kandjale olulisi autobiograafilise sisuga visuaalselt korrastatud või sümbolitena esitatud kujundeid ja narratiive (Summatavet 2005: 86-87). Eseme autorile võib artefakt sel juhul olla ka mäletamise ja suulise eneseväljenduse abivahendiks, mis aitab luua dialoogi ning tugevdada informandi ja kunstnikust uurija suhet esemelise pärandi 'tõlkimise' protsessis.

\section{Kokkuvõtteks}

Oskar Kallase eestvedamisel ja juhtimisel alguse saanud kunstnike vanavara kogumistöö lõi 20. sajandi alguses väärtusliku pretsedendi rahvakunsti ja professionaalse kunsti sidumiseks. Professionaalse kunstiõpetuse probleeme, mis on seotud folkloori ja uute kunstivaldkondade ühendamisega, on küll süvendanud 20. sajandi lõpukümnendi identiteedikriis ja kohalike tootmisvõimaluste piiratus, kuid Kristjan Raua ja Ants Laikmaa kunstiteoreetiliste tekstide taasavastamine võimaldab luua silda ühendamaks sajanditaguste kujutavate kunstnike tähelepanekuid tänaste uute võimalustega. Kunstiõppe ja loomingu sidumine välitöö meetoditega on uus võimalus uurida, miks Jaan Koortile kuulub aimdus, et meie rahva hinges ikka midagi peitub ning Kr. Raud huvitus paremast ja täielikumast ilmast, mida esemete ja rahvaluule kaudu väljendati. Nende kunstnike tähelepanekute valguses muutub taas aktuaalseks vajadus uurida, mida oleks Oskar Kallis võinud pakkuda eesti kunstile, kui tema loometee oleks olnud pikem.

\section{Kommentaarid}

${ }^{1}$ Näiteks Laikmaa venna ebaõiglane hukkamine või Raua valus märkus: Kui sagedaste on meie maa võeraste tallermaaks olnud, kui mitmed rahvad on seie sisse tunginud, rü̈̈stanud, hävitanud. Kauad ajad orjuses viibides on kõik oma hakatud halvaks pidama, ja see võerandamise himu on tänini püsimas rahva seas (EKLA f 74, sinine märkmik: 26).

${ }^{2}$ Mõiste vanavara võttis kasutusele Jakob Hurt. Juba 1867. aastast alates otsis Hurt sobivat terminit rahva mälestustele (kõne Vanemuise seltsis 1867 ja artiklis "Mis lugu rahva mälestustest pidada" Eesti Postimehe lisalehes 1871, nr 26, 27 lk 925). Ülo Tedre järgi püsis rahva mälestus käibel 1888. aastani ja asendus siis vanavaraga (Hurt 1989: 156). Terminit rahva mälestused ehk vanavara kasutas Hurt esmakordselt üleskutses "Paar palvid Eesti ärksamaile poegadele ja tütardele" 
(Olevik 1888, nr. 8, 9, 10,12), mis vallandas massilise ja tulemusrikka kogumistöö üle kogu Eesti. 18 aasta jooksul kogusid umbes 1000 kaastöötajat üle 114000 lehekülje rahvapärimusi. Enne seda üleskutset oli rahvapärimusi talletatud rohkem kui 15000 lehekülge (ÕES, Eestimaa Kirjanduslik Ühing, EKmS ja M. Veske) (Hurt 1989: 163).

${ }^{3}$ Matto: Selts oli 1840 kunstnike Ludvig Maydellilt kingitusena saanud 4 litografeeritud lehte eesti rahvarõivaste äärejoonistustega. Neid joonistusi võis ära kasutada rahvarõivaste kirjeldamisel, muutes mõnda osa ja kattes värviga, kus seda vaja. Selts laskis need joonistused trükiteel paljundada, koostas üleskutse, et saadetagu talle kirjeldusi ja pilte eesti rahvarõivastest. Aprillis 1842 saatis Selts selle üleskutse koos joonistuslehtedega laiali kõikidesse kihelkondadesse. Suurem osa neist joonistustest jäi tagasi tulemata, kuid mõned siiski tulid. On huvitav ära märkida, et esimesena sellele üleskutsele reageeris Dr. Fr. Kreutzwald Võrust. Joonistuste asemel hakkas Selts saama kohtadel valmistatud rahvarõivastes nukkusid, ka vähemaid rõivastusesemeid saadi (naiste mütsid, tanud). Nii see algas (G. Matto, EA varia 16:1).

${ }^{4}$ Keskkooliõpilasena külastas ta Eesti Kirjanduse Seltsi ja Eesti Rahva Muuseumi kõiki üldkoosolekuid, luges üleskutseid ajalehtedest ja üliõpilasena 1910. aastast alates oli juba ERMi algatustes kaastöötajaks (Matto 1965, EA varia 16: 2).

5 Oskar Kallas alustas kogumistööd 1892. aastal Saaremaal oma vanemate talus ning kinkis Eesti Üliõpilaste Seltsile 30 eset (EKLA f 186, m 202: 1, lk 3).

${ }^{6}$ Ants Laikmaa kogumistegevus kandis põhiliselt eriviisilist ilmet ja oli ainult vähesel määral seotud Õpetatud Eesti Seltsiga. Tema kogutud esemeist jõudis kinkide ja deposiitidena ERMi peamiselt vaipu ja tekstiile Tallinna ümbruse kihelkondadest (Jüri, Keila, Jõelähtme) aastail 1903-1906 (Sild 1972: 63).

7 Aastail 1905-1910 tegi Raud kogumistööd Õpetatud Eesti Seltsi etnograafilisele osakonnale. Esimesed kogumisreisid aastail 1905, 1906 ja 1907 toimusid kunstniku sünnikohas Viru-Jaagupis ja naaberkihelkondades. Aastal 1908 töötas Raud Keilas ja Ristil, 1909 Rõngus ning 1910 Jõelähtmes (Sild 1970: 61-62). Raua kogutud esemeid säilitatakse ERMis 339 numbrit, millest enamuses moodustavad tekstiilid: vaibad, käised, tanud, vööd jm (ERMi peakataloog 4971-4984, A 293, A 524).

${ }^{8}$ Kallase materjalid näiteks Eesti Rahva Muuseumi ajaloo kohta. 1893-1943. EKLA f 186, m 202: 1, lk 3; Kr. Raua kogumistööd tutvustava põhjaliku bibliograafia on koostanud 1981. aastal Lehti Viiroja; A. Laikmaa kohta on ilmunud ülevaade Eevi Pihlakult (Pihlak 1970b: 80-87); A. Laikmaa kirjad on avaldatud 2001. aastal.

${ }^{9}$ Kõiki kihelkonna viletsusi ei või vaesuse arvesse panna, osalt on nende hooletus sü̈̈di, iseäranis silmatorkavad on siin elanikkude mustus. Samuti on haridus väga madal. Koolisid on vähe ja kui neid ongi, siis ei käida neis (TAp 90. "Aruanne ainelise vanavara korjamise üle Martna khk. 1913”. Joosep Kliimand ja Paul Keerdo: 9).

${ }^{10}$ Olevat ka palju neid kes veel ebausu järel endid arstivad (vistriku arstimise viisid). (TAp 90. “Aruanne ainelise vanavara korjamise üle Martna khk. 1913”. Joosep Kliimand ja Paul Keerdo: 10)

${ }^{11}$ Raua töö rahvaluule ja eepose teemal algas 1914. aastal (Levin 2006: 177).

12 Peterburi koolis koolitati keskastme kunstkäsitöö spetsialiste (Raunam 1964: 11). 


\section{Allikad ja kirjandus}

\section{Eesti Kirjandusmuuseumi kultuurilooline arhiiv}

F 186, m 79: 27 Kallas, Oskar. Alutagusel vanavara korjamas. Kõne EÜS-is 11.10.1888. F 221, m 2: 19, 10/17. Laikmaa, Ants. Kolmkümmend kolm kirja Kristjan Rauale 23.2.1931-22.10.1940 ja d-ta.

F 221, m 5: 19. Kr. Raud, Käsikirjade fragmente ja märkmeid.

F 221, m 5: 19. Raud, Kristjan. Missugused olid meie muinasolevused? Kolmas aruanne korjatud ainete kohta. Trükitud aruanne EKLA f 157, m 14: 27.

F 157, m 13:3. Raud, Kristjan. Muinasjuttud ja muinaslooliste olevuste kirjeldused. I aruande materjal J. W. Weskile.

F 25, m 12: 28. Raud, Kristjan. Kristjan Raua kirjavahetus M. J. Eiseniga.

F 186, m 202: 1. O. Kallase materjale Eesti Rahva Muuseumi ajaloo kohta. 18931943.

F 74, sinine märkmik.

F 219, m 131: 9. A. Tassa, Kristjan Raud Kalevipoja illustreerijana.

F 126, m 3: 2 Kristjan Raud kirjad Johannes Sõsterile 14.1.1916-5.9.1917. Tallinnas 14.1.1916.

F 25, m 12: 28. Kristjan Raud M. J. Eisenile 27.03.1920 ja 28.03.1920.

F 173, m 16:1 Kristjan Raud, viiskümmend üheksa kirja K. E. Sööt'ile 31.12.1910_ 22.(28).10.1941.

F 219, m 131: 9. A. Tassa, Kristjan Raud Kalevipoja illustreerijana.

\section{Eesti Rahva Muuseumi käsikirjalised kogud}

TAp 4. Aruanne ERM heaks asjade korjamise üle Kolga randades, Kuusalu kihelkonnas 1910. a suvel. Kehras 18.09.1910.

EA varia 16. Matto, Gustav. Etnograafiliste esemete kogumine 50 aastat tagasi. Mälestusi Eesti Rahva Muuseumi tegevusest tema algaastail.

EA varia 16. Matto, Gustav (1965). Kristjan Raud - eesti vanavarakogumise suurmehi. Tema $100 \mathrm{ks}$ sünnipäevaks.

TAp 1, TAp 2. Triik, N. ja Pedak, Ed. N. Triiki ja Ed. Pedaku aruanne ainelise vanavara korjamise üle. Suvel 1909. ainelise vanavara korjamine - Iisaku khk, korjajad kunstnik N. Triik ja Ed. Pedak (üliõpilane).

TAp 66. Mõned täiendavad märkused minu vanavara korjamise kohta 1913. a. A. Kasekamp. 
TAp 182. Iisaku. Theodor Vaasi reisikirjeldus vanavara korjamisest ja andmeid rahvariiete kohta Iisaku ja Avinurme khk. Toodud 16. 12. 20.

G. Matto Aruanne ainelise vanavara korjamise üle Halliste kihelkonnas jaanikuul 1911: 2.

TAp 40. Vanavara korjamisel Muhus, Keinaste ja Kese saartel 1912. Paul Ruus.

TAp 161. Päevaraamat III Lüganuse khk. vanavara korjamisel 1915. a suvel, korjajad L. Subka, H. Weski, A. Kikajan, neiu Wälbe.

TAp 90. Aruanne ainelise vanavara korjamise üle Martna khk. 1913. Joosep Kliimand ja Paul Keerdo.

TAp 4 Kehras 18.09.1910. Aruanne ERM heaks asjade korjamise üle Kolga randades, Kuusalu kihelkonnas 1910. a.

TAp 82 Kullamaa. Üliõpilased J. Treumann, M. Tulmin 10. juunist 1913.

TAp 65 Päevaraamat. Korjaja Georg Gross, Ambla khk. 1913.

EJ 44 Võnnu ornamendid jm. G, Mooste 1912.

\section{Eesti Kunstiakadeemia raamatukogu}

Päts, Voldemar 1928. Riigi Kunsttööstuskooli õpilaste tööd. Riigi Kunsttööstuskool. Tallinn: RKK trükitöö õppetöökoda.

\section{Kirjandus}

Alle, August 1919. Eesti Kunsti ülevaatenäitus. Sotsiaaldemokraat nr 148-150.

Bogatyrev, Petr 1971. The Functions of Folk Costume in Moravian Slovakia. Approaches to semiotics, 5. Haag \& Pariis: Mouton.

Eesti Entsüklopeedia 7 1994. Tallinn: Eesti Entsüklopeediakirjastus.

Eesti Nõukogude Entsüklopeedia 2. 1987. Tallinn: Valgus.

Gens, Lev 1959. Jaan Koort - kunsti rahvuslikkusest. Tallinn: Kunst.

Helme, Sirje \& Kangilaski, Jaak 1999. Lühike Eesti kunsti ajalugu. Tallinn: Kunst.

Honko, Lauri 1998. Folklooriprotsess. Mäetagused: Hüperajakiri 6, lk 56-84 (http:// www.folklore.ee/tagused/nr6/index.html\#teo).

Hurt, Jakob 1989. Mida rahvamälestustest pidada. Ülo Tedre (toim). Tallinn: Eesti Raamat.

Kallas, Oskar 2006. Oskar Kallase päevik (1. osa). Piret Õunapuu (koost). Vanavara kogumisretkedelt 1. Tartu: Eesti Rahva Muuseum.

Kangro-Pool, Rasmus 1961. Kristjan Raud 1865-1943. Tallinn: Eesti NSV Kunst. 
Kirme, Kaalu 1989. Jaan Koorti päevaraamat. Tallinn: Kunst.

Kirme, Kaalu 1999. Autoportree silmusega. Adamson-Ericu dokumentaalne eluromaan. Tallinn: Kunst.

Koort, Jaan 1911. Rahvusline kunst. Eesti Kodu nr 3.

Koort, Jaan 1926. EKKKK V kunstinäitus. Päevaleht nr. 245, 10.09.26.

Kuma, Helene 2001. Rahvakunsti traditsioon Eesti tarbekunstis. Rahvatraditsioonidest Eesti kunstis. Viljandi: Viljandi Kultuurikolledži talukujunduse ja rahvusliku käsitöö kateeder ja Eesti Kunstiakadeemia tekstiilikunsti osakond.

Laipmann, Hans 1903. Üleskutse. Teataja. 15. november.

Laikmaa, Ants 2001. Kas tõesti mina: kirjad läbi elu. Vaike Tiik (toim). Tartu: Ilmamaa.

Lehtinen, Ildikó 1984. Korut. Rahwaan puku. Helsinki: Museovirasto.

Lehtinen, Ildikó 1994a. Tscheremisser Schmuck. Ethnographische Untersuchung. Helsinki: Travaux ethnographiques de la Societé Finno-Ougrienne 14.

Lehtinen, Ildikó 1994b. Korujen sanomat. Ovat korut ylellisyys tai välttämättömyys. Suomen Museo 101. vuosikerta. Helsinki: Suomen muinaismuistoyhdistys.

Lehtinen, Ildikó 1999. Marien mekot. Volgansuomalaisten kansanpukujen muutoksista. Helsinki: Suomalais-Ugrilainen Seura.

Leinbock, Ferdinand 1934. Eesti Rahva Muuseum 1909-1934. Eesti Rahva Muuseumi aastaraamat $I X-X$, lk 1-48. Tartu.

Levin, Mai 2006. Ühest sajandist teise. Kristjan ja Paul Raud. Tallinn: Kumu.

Lévi-Strauss, Claude 2001. Metsik mõtlemine. La pensée sauvage. Tallinn: Vagabund.

Linnus, Jüri 1970a (toim). Eesti NSV Riikliku Etnograafiamuuseumi soome-ugri rahvaste etnograafilised kogud. Läänemeresoomlaste rahvakultuurist. Eesti NSV Etnograafiamuuseum. Tallinn: Valgus.

Linnus, Jüri 1970b. Ilmari Manninen ja Eesti Rahva Muuseum. Läänemeresoomlaste rahvakultuurist, lk 247-258. Eesti NSV Etnograafiamuuseum. Tallinn: Valgus.

Lotman, Juri 1999. Semiosfä̈̈rist. Tallinn: Vagabund.

Manninen, Ilmari \& Leinbock, Ferdinand 1925. Rahvateaduslikud kogud Eesti Rahva Muuseumis. Eesti Rahva Muuseumi aastaraamat I, lk 134-144. Tartu.

Nirk, Endel 1977. Kaanekukk. Lugu Ants Laikmaa elust ja ettevõtmistest. Tallinn: Kunst.

Nurk, Tiina 1972. Eesti kunstiõpilased Stieglitzi kunsttööstuskoolis. Tartu Riikliku Kunstimuuseumi almanahh III. Tartu.

Pert, J. 1936. Jaan Koort oma töödega. Kunst ja Kirjandus nr 32, 11.10.

Pihlak, Evi 1969. Nikolai Triik. Tallinn: Eesti Kunst. 
Pihlak, Evi 1970a. Kristjan Raud Eesti kunstielu organisaatorina käesoleval sajandil. Kristjan Raud, Ants Laikmaa. Lehti Viiroja (toim). ENSV Teaduste Akadeemia Ajaloo Instituut, kogumik Kristjan Raua ja Ants Laikmaa 100. sünniaastapäevale pühendatud teaduslike konverentside ettekannetest 1965/1966. Tallinn: Kunst.

Pihlak, Evi 1970b. Ants Laikmaa Eesti kunstielu keskse kujuna sajandi esimestel aastakümnetel. Kristjan Raud, Ants Laikmaa. Lehti Viiroja (toim). ENSV Teaduste Akadeemia Ajaloo Instituut. Kogumik Kristjan Raua ja Ants Laikmaa 100. sünniaastapäevale pühendatud teaduslike konverentside ettekannetest 1965/1966. Tallinn: Kunst.

Pulst, August 2006. Vanavara kogumisretkedelt 2. Piret Õunapuu (koost). Tartu: Eesti Rahva Muuseum.

Põldmäe, R[udolf]. 1942. Ants Laikmaa rahvaluule kogujana. Eesti Sõna nr 272. Tartu.

Raud, Kristjan 1904. Kunst Eesti käsitöös. Linda nr 34, lk 26/VIII. Tartu.

Raud, Kristjan. Paar sõna Eesti rahva korjamisest. Postimees nr 229, 15.10.1905.

Raud, Kristjan 1907. Hurti museumi asjus. Postimees 27. jaanuar.

Raud, Kristjan 1909. Mötteid Eesti kunstnikkude ja kunstiöpilaste tööde näituse puhul. Postimees 16.04 .

Raud, Kristjan 1911. Oli ennemuiste nõnda, Eesti Kultura I.

Raud, Kristjan 1913. Missugused olid meie muinasloolised olevused? Postimees nr 113, 18./31. V.

Raud, Kristjan 1914. Endised ehteasjad ja meie naisterahvas, Postimees nr 124, 5./18. VI.

Raud, Kristjan 1914. Meie mälestusmärkidest. Postimees nr 112.

Raud, Kristjan 1937. Meie oma kunstist. EKKKY Kunsti Album III. Tallinn.

Raud, Kristjan 1938. Syvenemisest. Kunsti Yhing Pallas 1918-1938. Tartu.

Raunam, Oskar 1964. Õppeasutuse rajamise ja arengu ajaloost. Teder, I (toim). Eesti NSV Riiklik Kunstiinstituut. 50 aastat kunstialast haridust. Tallinn: Eesti NSV Kunst.

Scrivener, Stephen AR 2006. Visual Art Practice Reconsidered: Transformational Practice and the Academy. Antoloogia The Art of Research. Research Practices in Art and Design. Publication series of University of Art and Design Helsinki. Jyväskylä: Gummerus Kirjapaino OY.

Sild, Hilja 1970. Kristjan Raud ja vanavara suurkogumine. Kristjan Raud, Ants Laikmaa. Lehti Viiroja (toim). ENSV Teaduste Akadeemia Ajaloo Instituut, kogumik Kristjan Raua ja Ants Laikmaa 100. sünniaastapäevale pühendatud teaduslike konverentside ettekannetest 1965/1966. Tallinn: Kunst.

Sild, Hilja 1972. Kunstnike kaasabist Eesti Rahva Muuseumi rajamisel ja vanavara kogumisel. Tartu Riikliku Kunstimuuseumi almanahh III, Tartu. 
Suits, Gustav 1905. Noorte püüded. Noor Eesti I. Tartu.

Summatavet, Kärt 2005. Folk Tradition and Artistic Inspiration. A Woman's Life in Traditional Estonian Jewellery and Crafts as Told by Anne and Roosi. Publication series of University of Art and Design Helsinki. Tallinn: Tallinna Raamatutrükikoda.

Summatavet, Kärt 2006. Tradition, Inspiration and Artistic Innovation. Antoloogia The Art of Research. Research Practices in Art and Design. Publication series of University of Art and Design Helsinki. Jyväskylä: Gummerus Kirjapaino OY.

Tiik, Vaike 1964. Ants Laikma. Tartu Riikliku Kunstimuuseumi almanahh nr 1. Tartu.

Tiik, Vaike 1972. Eesti kunst ja "Noor-Eesti". Tartu Riikliku Kunstimuuseumi almanahh III. Tartu.

Toom, Maire 2004. Riigi Kunsttööstuskool 1914-1940. Eesti Kunstiakadeemia toimetised 14. Tallinn: Eesti Kunstiakadeemia.

Triik, Nikolai \& Pedak, Eduard 2007. Vanavara kogumisretkedelt 3. Piret Õunapuu (koost). Tartu.

Tuglas, Friedebert 1910. Üks põhjamaa pärl. "Noor-Eesti” ajakiri 1910/1911. Tartu.

Turpeinen, Outi 1999. Museon ja esineiden suhde. Tutkimus museoista syntyneistä mielikuvituksista, vitriineistä ja museoita kommentoineista taiteilijoista, ARTTU! 5/99. Helsinki.

Viires, Ants 1992. Rahvakunsti olemus ja piirid. ERMi aastaraamat XXXIX, lk 7-22. Tartu.

Viires, Kadri 2006. Joonistatud dokumendid. Mäetagused: Hüperajakiri 29, lk 91-110. Tartu.

Viiroja, Lehti 1981. Kristjan Raud 1865-1943: looming ja mõtteavaldused. Tallinn: Kunst.

Wõhandu, Hans 1905. Laipmann ja ta kunstikool Tallinnas. Olevik 1905, 09.10.

Õunapuu, Piret 1990. Oskar Kallas ja Eesti Rahva Muuseum. Eesti Rahva Muuseumi aastaraamat XXXVII, lk 155-169. Tartu.

Õunapuu, Piret 2001. Ja siis tuli Soomest noor mees Ilmari Manninen... Paar sammukest XVIII. Eesti Kirjandusmuuseumi aastaraamat, lk 115-136. Tartu.

Õunapuu, Piret 2007. Eesti Rahva Muuseumi algaastate suurkogumised. Eesti Rahva Muuseumi aastaraamat L, lk 11-42. Tartu. 


\title{
Summary
}

\section{Reflections on Art, Kristjan Raud and Collecting Tangible Heritage}

\author{
Kärt Summatavet
}

Key words: fine arts, folk art, fieldwork, professional art education

The article explores the problems which emerged in professional art education during the 20th century in order to explain the reasons for the unpopularity of artistic creation dealing with local visual identity in Estonia in the last decade of the century. The article also investigates the activities of artists who worked at interpreting and collecting tangible heritage at the beginning of the 20th century. The application of empirical experience and artistic categories in linking folk art and professional art is examined in the folklore-related creative and pedagogical work of Kristjan Raud. The methods and goals of interpreting folklore that dominated professional art education at the beginning of and in the second half of the 20th century are compared. The possibilities of fieldwork methods available for examining the repertoires of the authors of artefacts in traditional communities and for their use in the search for sources of inspiration are explained.

While in the last few years, elements of ethnology and folklore have experienced a rising trend in the world's high fashion, design and contemporary arts, Estonia has devoted little attention to its own traditions in the 21st century. The deeper roots of the problem lie in the limited understanding of culture and history among the younger generation and the lukewarm interest of art politicians in artistic creation that deals with the local identity. Estonian artists working at the beginning of the 20th century were transmitters of tradition and had more direct ties to folklore as a source of inspiration. Kristjan Raud encouraged his young colleagues and art students to participate in the collection of folklore and traditional objects in villages and most of the prominent artists of that period made at least one fieldtrip to collect tangible heritage for the Estonian National Museum.

Raud emphasized that the artefacts decorated with the patterns of previous generations were inspired by profound ideas and were not arranged randomly. He was convinced that the previous generations expressed in their creative work old spiritual values, profound feelings and the experience of everyday life, they had great artistic talent; Raud also pointed out the educational, developmental and artistically directing influence of tangible heritage.

Artefacts symbolise a certain skill of thinking and writing in oral culture, a visible expression of the ethnic language and mentality. Fieldwork provides an artist an opportunity to examine the practical needs of the authors of tangible heritage, and in addition to preferences in taste, to also get a better view of the mindset, traditional environment, the existing norms and creative practices of the transmitters of tradition. Texts presented in visual form "speak" in a coded language, which is acceptable in the community, and reflect the creative process of the members of the community who 
have created the artefacts as a composite system. On the one hand, the messages these artefacts convey are regulated by standards that are shared by the community and mutually agreed upon, while on the other hand they convey autobiographical visual narratives of the producer. The important factor here is the relating of professional art education, creation, and fieldwork to issues of the unexplored authorship of Estonian tangible culture and the context of creative self-expression practices. 